\title{
Cardioplegia sangüínea contínua normotérmica
}

\author{
Domingo M. BRAILE*, Roberto V. ARDITO*, Marcos ZAIANTCHICK*, José L. Verde SANTOS*, Marcelo \\ José F. SOARES*
}

RBCCV $44205-83$

BRAILE, D. M.; ARDITO, R. V.; ZAIANTCHICK, M.; SANTOS, J. L. V.; SOARES, M. J. F. - Cardioplegia sangüinea contínua normotérmica. Rev. Bras. Cir. Cardiovasc., 4(2): 109-138, 1989.

RESUMO: Os autores discutem o emprego da cardioplegia, bem como sua composição. A parada imediata dos batimentos pode ser conseguida com soluçōes cardioplégicas cristalóides ou sangüineas, oxigenadas ou não. $\mathrm{O}$ agente que leva o coração à parada pode ser potássio, magnésio, procaina ou, mesmo, quelantes e bloqueadores de cálcio associados entre si ou não, contando com a edição da hipotermia ou não. Deve-se ficar atento para a falsa sensação de proteção a que a baixa temperatura possa nos induzir, uma vez que o frio, por si só, não é suficiente para manter o miocárdio viável por longos períodos. Substratos, como glicose e oxigênio, devem ser fornecidos durante o período de clampeamento aórtico. para garantir algum metabolismo aeróbio, nesse período. A adição de outros substratos, como glutamato, aspartato e lactato, assim como ATP ou creatina fosfato, precursores de intermediários do ciclo de Krebs, podem melhorar muito a proteção miocárdica. A infusão de cardioplegia sangüinea normotérmica de forma contínua mantém as necessidades metabólicas básicas para a sobrevivência das células. A membrana celular, com todas as suas funçōes estruturais e secretoras, é o ponto mais sensivel à injúria isquêmica. Os removedores de radicais livres (scavengers) são protetores indiretos da membrana celular. A cardioplegia retrógrada permite melhorar a distribuição das soluçōes na árvore coronariana, sendo muito útil nas reoperaçōes. Ela deve fazer parte da tática cirúrgica, sem esquecermos suas limitaçōes. O momento da reperfusão é o mais importante da proteção miocárdica; é nesse período que ocorre a liberação de radicais livres. $\mathrm{O}$ uso de removedores (scavengers) pode melhorar as condiçōes e o resultado da reperfusāo. A cardioplegia sangüinea oxigenada e normotérmica enriquecida com substratos, antes usada em casos extremamente graves, por disfunção muscular em isquemia miocárdica severa, ou por ausência de proteção adequada, durante a fase de isquemia e/ou reperfusāo, foi expandida para todos os casos. É recomendado que o coração tenha, sempre, suas câmaras drenadas, evitando-se qualquer aumento na tensão da parede, o que levaria a maior consumo de oxigênio. Os autores descrevem a técnica e as soluçōes cardioplégicas aplicadas no Serviço de Cirurgia Cardíaca do IMC e os resultados obtidos com o uso das mesmas. Concluem ser satisfatório o uso de cardioplegia normotérmica modificada e reperfusão assistólica, enriquecidas por aminoácidos, na preservação da função miocárdica e na reversāo dos danos isquêmicos.

DESCRITORES: proteção miocárdica, cardioplegia; bloqueadores de cálcio; radicais livres.

\section{INTRODUÇĀO}

A evolução das técnicas de proteção miocárdica tem seguido de perto a evolução da própria cirurgia cardiaca, alternando-se em importância e em interesse, de acordo com os desafios a que se têm proposto aqueles que se dedicam à especialidade, compreendendo: farmacologistas, fisiologistas, patologistas, perfusionistas, anestesistas e cirurgiōes.

Em 1955, MELROSE et alii ${ }^{96}$ publicaram, no Lancet, uma comunicação preliminar intitulada "Parada Cardíaca

Trabalho realizado no Instituto de Moléstias Cardiovasculares de Săo José do Rio Preto, SP. Brasil

Apresentado ao 16: Congresso Nacional de Cirurgia Cardiaca. Sào Paulo, SP, 7 e 8 de abril, 1989

* Do Instituto de Moléstias Cardiovasculares de São José do Rio Preto.

Endereço para separatas: Domingo M. Braile. Rua Castelo D'Água, 3030. 15015 São José do Rio Preto. SP. Brasil. 
BRAILE, D. M.; ARDITO, R. V.; ZAIANTCHICK, M.; SANTOS, J. L. V.; SOARES, M. J. F. - Cardioplegia sangũínea contínua normotérmica. Rev. Bras. Cir. Cardiovasc., 4(2): 109-138, 1989.

Eletiva", com a qual lançaram as bases da cardioplegia. $\mathrm{O}$ interessante é que a técnica de Melrose empregava sangue como veículo do citrato de potássio, inaugurando, portanto, a era da proteção miocárdica com cardioplegia sangüínea. Apesar da técnica ter tido ampla difusão e aceitação, na época, sendo adotada por EFFLER et alii $^{34}$ e KIRKLIN et alii ${ }^{6}$, a partir de 1959 surgiram trabalhos demonstrando a possibilidade de necrose celular pela própria açāo do citrato de potássio ${ }^{53,144}$. A concentraçāo do potássio na solução proposta por Melrose era de $200 \mathrm{mEq} / \mathrm{l}$, o que, sem dúvida, explica o efeito indesejado.

A introdução, por COOLEY et alii ${ }^{29}$, da parada anóxica, que parecia produzir os mesmos resultados sem os inconvenientes dos controles necessários para a cardioplegia, além das novas técnicas de circulaçāo extracorpórea e o interesse dos cirurgiōes pela parte técnica do ato operatório, desviaram a atenção de grande parte dos pesquisadores do campo da proteção miocárdica. A própria publicação original de COOLEY et alii ${ }^{30}$, em 1972 , em que descreveu o "stone heart" (contratura isquêmica do coração), abriu novamente o campo para a proteção miocárdica durante a isquemia. Surgem, então, os primeiros trabalhos de $\mathrm{KIRSCH}$ et alii ${ }^{68}$, mostrando a experiência clínica com o uso de cardioplegia cristalóide contendo aspartato de magnésio, procaína e sorbitol. A conclusão dos autores é de que o método é superior à parada isquêmica simples e que pode, até, competir com a perfusão coronariana contínua.

É interessante notar que o espirito de observação pode levar a raciocínios corretos, mesmo antes que o mecanismo como um todo seja entendido. O uso do aspartato de magnésio mostrava melhores resultados que o cloridrato do mesmo sal, o que fica claro, hoje, à luz dos conhecimentos a respeito do enriquecimento do substrato com aspartato ${ }^{123}$.

Em 1973, em um artigo publicado pelo grupo de Shumway, GRIEPP et alii ${ }^{50}$, estabeleceram-se as bases da proteção miocárdica através da hipotermia local profunda, concluindo ser o método adequado para proteção do miocárdio, durante até 90 minutos de clampeamento aórtico. TYERS et alii ${ }^{140}$, em 1974 , seguindo no caminho da hipotermia, têm a idéia de perfundir a raíz da aorta com solução de Ringer lactato gelado. Aliando esta técnica à hipotermia de superfície e conseguindo melhores resultados, lançaram, também, a idéia de acrescentar ao Ringer outras substâncias que pudessem melhorar a proteção miocárdica. Apesar dos trabalhos experimentais com o uso do potássio para indução da cardioplegia aparecerem, na literatura, de forma esporádica, GAY \& EBERT ${ }^{47}$ publicaram, em 1973 , os resultados favoráveis do uso de uma solução de $20 \mathrm{mEq} / \mathrm{l}$ de potássio, osmolarmente balanceada, com a qual conseguiram benefícios metabólicos e funcionais para o miocárdio, sem qualquer alteração estrutural. Em 1977, LEVITSKY et alii ${ }^{82}$ mostraram que a reperfusão intermitente por 5 minutos, após clampeamento aórtico normotérmico de 15 minutos, é insuficiente para restaurar o equilibrio metabó- lico e pode, mesmo, ser prejudicial (lesão de reperfusão), sugerindo, como alternativa, o uso de cardioplegia induzida pelo potássio. No mesmo ano, dois estudos clínicos lançaram, definitivamente, a cardioplegia como método de escolha para a proteção miocárdica. BRAIMBRIDGE et alii ${ }^{15}$, em 1977, compararam 2 grupos de pacientes. O primeiro grupo representava pacientes operados entre 1972 e 1975, nos quais foi usada perfusão contínua das coronárias com o coração batendo, técnica corrente e admitida como ideal, na época. O segundo representava pacientes operados em 1975 e 1976, nos quais o miocárdio foi preservado pela solução do Hospital St. Thomas n: $1^{80}$. Este grupo mostrou melhor preservaçăo miocárdica através de análises citoquímicas e melhor performance cardiaca, desde que a solução de indução fosse repetida de tempos em tempos. A facilidade técnica com o emprego da cardioplegia em muito superava as dificuldades da perfusão coronariana constante ${ }^{13}$. Outra publicaçāo, também de grande importância, é a de ROE et alii ${ }^{119}$, na qual apresentaram os resultados favoráveis em 204 pacientes com o emprego de cardioplegia induzida por solução de potássio gelada na concentração de $20 \mathrm{mEq} / \mathrm{l}$, com mortalidade de apenas $1 \%$ relacionada às causas cardíacas. $\mathrm{O}$ trabalho, apresentado no 2 . Encontro da Samson Thoracic Surgical Society, provocou grande interesse e discussões. Desde então, o número de especialistas preocupados com a proteção miocárdica cresceu exponencialmente e o número de pesquisas e publicaçōes aumentou de forma inusitada.

Em 1980, McGOON ${ }^{94}$ publicou um editorial sobre o número fantástico de variáveis que acompanha a possibilidade de proteção miocárdica no campo cirúrgico e na experimentação, e a abundância de publicaçōes resultantes, levando a área a um verdadeiro caos. Em 1985 , o mesmo autor ${ }^{93}$ voltou a publicar um editorial tratando, outra vez, da questão e fazendo um catálogo da literatura pertinente na língua inglesa.

Para o cirurgião cardíaco, que vive o dia-a-dia dos pacientes cada vez mais complexos, incluindo desde recém-nascidos até idosos com mais de 80 anos, acompanhar as publicaçōes sobre proteção miocárdica não é tarefa fácil, mesmo porque os dados apresentados são, por vezes, conflitantes, quando não analisados à luz de uma compreensão mais profunda e global. Não temos pretensão de analisar toda essa literatura, mas gostaríamos de discutí-la, apresentar a nossa experiência e descrever, detalhadamente, as técnicas que temos empregado nos diferentes casos, com resultados compensadores.

\section{Dano Isquêmico}

Dano isquêmico é o resultado do desbalanço entre oferta e consumo de energia durante o período de clampeamento aórtico.

Oferta é quando o coraçāo está normalmente perfundido e sua energia é produzida pela via aeróbia, com 
BRAILE, D. M.; ARDITO, R. V.; ZAIANTCHICK, M.; SANTOS, J. L. V.; SOARES, M. J. F. - Cardioplegia sangüínea continua normotérmica. Rev. Bras. Cir. Cardiovasc., 4(2): 109-138, 1989.

liberação de 38 moles de adenosina trifosfato (ATP) para cada mol de glicose metabolizada. No momento em que a aorta é clampeada, o metabolismo cardíaco torna-se fundamentalmente anaeróbio, com a utilizaçāo de glicogênio e glicose por outra via, produzindo apenas 2 moles de ATP por mol de glicose.

Dependendo da circulação colateral para as coronárias, o metabolismo aeróbio pode ser mantido e isto explica alguns casos de longos clampeamentos aórticos com bom resultado clínico.

Principalmente nos pacientes coronarianos, existe solicitação para o desenvolvimento de uma rica circulação colateral, que poderia fornecer o oxigênio necessário à produção de energia suficiente para manter a integridade celular durante a isquemia ${ }^{15}$.

De outra forma, o próprio metabolismo anaeróbio mantém a integridade celular ${ }^{17}$, caso:

1) haja suficiente substrato, glicose ou glicogênio; 2) não ocorra acúmulo de lactato e citrato com redução do $\mathrm{pH}$ a níveis críticos; 3 ) não haja inibição metabólica de enzimas essenciais, como, por exemplo, a fosforofrutoaminase.

\section{Consumo}

Consumo é o principal gasto de energia do coração. É determinado pelo seu trabalho eletromecânico e tensão da parede. Pequenas quantidades de energia (cerca de $10 \%$ do total) são utilizadas para manter o metabolismo cardíaco intrínseco e os gradientes transmembrana. Esse gasto metabólico pode ser bastante reduzido pela hipotermia ${ }^{16,25}$. O coração parado necessita de 1 $\mathrm{ml}$ de $\mathrm{O}_{2}$ por $100 \mathrm{~g}$ de miocárdio a $37^{\circ} \mathrm{C}$, ou de 0,3 $\mathrm{ml}$ de $\mathrm{O}_{2}$ por $100 \mathrm{~g}$ de miocárdio a $22^{\circ} \mathrm{C}$. Em contraste, o coração batendo ou fibrilando gasta $2,0 \mathrm{ml} \mathrm{de} \mathrm{O}_{2}$ por $100 \mathrm{~g}$ de miocárdio a $22^{\circ} \mathrm{C}$ e 6 a $8 \mathrm{ml}$ de $\mathrm{O}_{2}$ por 100 $\mathrm{g}$ de miocárdio a $37^{\circ} \mathrm{C}$. Quando o coração pára por anóxia, após o clampeamento aórtico, ocorre uma diminuição das reservas de ATP a niveis tão críticos que impedem o acoplamento eletromecânico e o funcionamento da bomba de sódio e potássio, responsável por manter o potássio dentro da célula. Quando se faz uma parada farmacológica, pelo contrário, a membrana é despolarizada quimicamente e o coração é levado a um estado de diástole sustentada. Nesta condição, não se perde energia na produção de trabalho eletromecânico desnecessário. Toda a energia economizada pode ser utilizada para manter o estado diastólico que está relacionado com a tensão da parede e a temperatura. Para que a diástole seja mantida, é necessário que o cálcio intracelular, responsável pela contração, seja ativamente bombeado para o retículo sarcoplasmático. $O$ cálcio intracelular residual é o responsável pela tensão da parede ${ }^{20}$. Lembramos que o mecanismo de seqüestração do cálcio é ativo, depende da sua concentração intracelular e impli- ca em gasto de energia, que deve ser rigorosamente economizada durante a parada cardíaca.

É interessante saber que a hipotermia diminui o consumo metabólico como um todo, porém reduz, também, a atividade da bomba de cálcio, podendo levar a maior concentração celular do mesmo, maior tensão da parede e maior gasto de energia.

\section{Conseqüência da Isquemia}

A isquemia provoca falta de oxigênio com ausência de produção de energia, levando ao acúmulo de ácido lático pela inabilidade de piruvato entrar no ciclo do ácido cítrico (ciclo de Krebs). Disto decorre um ambiente ácido impróprio, mesmo para a produção de energia por via anaeróbia. Por sua vez, a falta de energia altera o funcionamento das bombas ativas de sódio, potássio e cálcio, de tal forma que: 1) entra sódio para dentro da célula, acompanhado por água, com conseqüente edema celular; 2) o potássio intracelular abandona a célula, diminuindo $\circ$ gradiente transmembrana, que fica despolarizada e o coração, parado; 3 ) como a concentração de potássio extracelular torna-se maior, existe facilitação para entrada de cálcio na célula, com o conseqüente aumento da tensão da parede e necessidade de maior gasto de energia pelo bombeamento de maiores quantidades de cálcio para o retículo sarcoplasmático (seqüestração).

A impossibilidade de manter o cálcio seqüestrado leva à contratura miocárdica pelo aumento exagerado do cálcio intracelular. Esta contratura ocorre durante a isquemia porém piora, de muito, após o desclampeamento aórtico, quando o fluxo de cálcio é maior (lesão de reperfusão).

\section{Cardioplegia}

A cardioplegia farmacológica busca eliminar as já citadas conseqüências da isquemia pela criação de um ambiente no qual o consumo de energia possa ser diminuído, ao mesmo tempo em que se consiga aumentar a sua produção para suprir a demanda básica.

São requisitos principais para que uma cardioplegia possa ser usada clinicamente: 1) proteger o coração ao invés de lesá-lo pelos seus próprios componentes: 2) distribuir os componentes farmacológicos por todo o miocárdio, em quantidades suficientes para produzir o efeito desejado; 3 ) ter seu efeito prolongado pelo tempo em que durar o clampeamento aórtico; 4) ter sido testada experimentalmente.

A não atenção a estes princípios tem levado à grande confusāo existente a respeito das diferentes composiçōes e técnicas de cardioplegia. Tem levado, também, à desconfiança de alguns segmentos da comunidade científica, em virtude de experiências clínicas mal suce- 
BRAILE, D. M.; ARDITO, R. V.; ZAIANTCHICK, M.; SANTOS, J. L. V.; SOARES, M. J. F. - Cardioplegia sangüinea contínua normotérmica. Rev. Bras. Cir. Cardiovasc., 4(2): 109-138, 1989.

didas e da impossibilidade de comparar os resultados experimentais com os clínicos, que nunca são tão ruins ou tão bons como aqueles ${ }^{20}$.

Um exemplo evidente deste problema é a cardioplegia proposta por Melrose que, por apresentar concentração inadequada de potássio, levou a resultados errôneos e, apesar do mérito da sua originalidade, acabou por atrasar em aproximadamente 20 anos a implementação da cardioplegia. Os trabalhos de TYERS et alii ${ }^{139}$. 140 demonstraram que o problema com a solução de Melrose não era a sua composiçāo, mas apenas a concentração do potássio. Os trabalhos de FOLLETTE et alii ${ }^{43}$ mostraram que, usando-se a mesma composição proposta por Melrose e ajustando-se a dose, é possivel obter excelente proteção miocárdica, até quando comparada com perfusão coronariana contínua ${ }^{42,44}$.

Outro problema a ser entendido é que o uso da cardioplegia ocorre no coração contido dentro do organismo e, além disto, ele sempre apresenta uma doença de base, pois, de outra forma, nāo estaria indicada a intervenção cirúrgica.

BUCKBERG ${ }^{20}$ ressalta a diferença da preservação do coração in vivo e in vitro. In vitro, o coração é retirado do organismo e pode ser conservado até 24 horas, mantendo suas funçōes, desde que seja protegido por uma solução que contenha os componentes na mesma proporção dos integrantes intracelulares, eliminando-se, assim, os gradientes transmembrana ${ }^{5}$. Contudo, in vivo esta mesma soluçāo falha em preservar o coração, se este for submetido a isquemia de 2 ou 3 horas. Aquele autor enfatiza a necessidade de considerar o coração dentro do organismo como parte de um todo, sofrendo a influência, principalmente, da circulação colateral não coronariana, que "lava" os componentes da cardioplegia fornecidos ao coração no momento da parada. São palavras de Buckberg: "A falta de reconhecimento dos investigadores em considerar a importância da circulação colateral na cardioplegia clínica criou um enorme fluxo de literatura, que tem servido muito mais para confundir do que para esclarecer os cirurgiōes" 20 .

A circulação colateral aumenta muito nas doenças coronarianas, na hipertrofia ${ }^{16}$ e na cianose. É durante o pinçamento aórtico que esta circulação se manifesta mais acentuadamente. $\mathrm{O}$ interessante é que, às vezes, o volume de sangue fornecido pela circulação colateral é suficiente para manter o metabolismo celular, mesmo no pinçamento aórtico simples. Outras vezes, é insuficiente, levando a consequeencias desastrosas. Quando se usa proteção miocárdica, a circulação colateral acaba retirando os componentes da cardioplegia e aquecendo - miocárdio, sem levar a ele a quantidade necessária de oxigênio, principalmente no caso do coração voltar a bater ou fibrilar, numa temperatura mais elevada.

Acreditamos que todos reconhecem a presença e a importância da circulação colateral e estāo cansados de ver sangue saindo dos óstios coronarianos durante a troca de valva aórtica, ou das arteriotomias durante realização das anastomoses coronarianas, mesmo com a aorta pinçada.

Se o coração volta a bater ou fibrilar, depois de ter sido resfriado e parado por cardioplegia farmacológica, é porque os componentes químicos foram lavados e o coração voltou a se aquecer pela circulação colateral, dispondo, agora, de energia suficiente para fazer o acoplamento eletromecânico. Os corações que param por isquemia quase nunca voltam a bater, pela grande depleção de ATP que apresentam. Raramente surgem casos em que a circulação colateral é tâo intensa que permite a restauração de níveis de energia suficientes para volta da atividade eletromecânica, levando, contudo, ao desbalanço de oferta e demanda de oxigênio. Nas reoperaçōes de coronarianos com artérias mamárias pérvias, este modelo fica implementado e o controle da situaçăo exige táticas especiais, quais sejam, o pinçamento do pedículo da mamária ou hipotermia profunda.

A circulação colateral não tem só desvantagens. Provavelmente, tem protegido muitos miocárdios contra cardioplegias completamente sem sentido, retirando do contato com as células componentes deletérios para as mesmas e repondo tampōes, substratos e oxigênio em quantidades, se não ideais, suficientes para manter a viabilidade dos tecidos em níveis aceitáveis. Cientes de que a cardioplegia é transitória, do ponto de vista clínico, é conveniente desenvolver soluçōes simples e seguras que possam ser usadas pelo coração e mantê-lo parado e protegido, diminuindo os efeitos da circulação colateral durante o pinçamento aórtico.

\subsection{Composição da Cardioplegia}

Como já foi enfatizado, o que se deseja com a cardioplegia química é parar o coração com segurança, criar um ambiente favorável para a produção contínua de energia e eliminar os efeitos deletérios da isquemia e da reperfusão.

Assim, a composição da cardioplegia deve ter elementos que permitam: 1) parar o coração imediatamente, evitando depleção de energia; 2) esfriar o miocárdio, diminuindo a demanda metabólica, ou, quando mantido aquecido, fornecer fluxo suficiente para manutenção do metabolismo aeróbio; 3 ) fornecer substratos para o metabolismo aeróbio, ou anaeróbio, ou ambos; 4) ter efeito tampão contra a acidose, que impede o metabolismo; 5) estabilizar a membrana com drogas específicas; 6) evitar o edema pela hiperosmolaridade.

Além disto, é preciso ter certeza de que a composição e a concentraçāo das soluçōes tenham sido testadas de forma experimental, com resultados absolutamente seguros $20,21,43.139$.

Esclarecendo os itens acima citados, vamos analisar cada tópico em separado, à luz dos conhecimentos 
BRAILE, D. M.; ARDITO, R. V.; ZAIANTCHICK, M.; SANTOS, J. L. V.; SOARES, M. J. F. - Cardioplegia sangüínea contínua normotérmica. Rev. Bras. Cir. Cardiovasc., 4(2): 109-138, 1989.

que têm sido adquiridos ao longo dos 30 anos de cardioplegia.

\subsection{Parada Cardíaca}

A parada imediata dos batimentos pode ser conseguida com soluçōes cardioplégicas cristalóides ou sangüineas, oxigenadas ou năo. Contudo, as soluçóes cardioplégicas cristalóides não oxigenadas levam à depleção acentuada de ATP, se existir qualquer atividade eletromecânica durante sua induçāo ${ }^{111}$. Quando se usa cardioplegia oxigenada ${ }^{23,58}$, seja cristalóide ${ }^{9,11,134}$, sangüinea $^{101.145}$, ou com fluosoli34, é possível, além de economizar energia durante a fase de indução, até aumentá-la, fazendo uma reserva de ATP antes da isquemia, que prolongará o período de segurança durante o clampeamento aórtico. Um artigo recente de WIT et alii ${ }^{148}$, contudo, mostrou, experimentalmente em coraçōes de ratos, que a função ventricular fica deprimida com o uso da cardioplegia cristalóide oxigenada, apesar dos níveis de ATP se manterem em niveis aceitáveis. Por outro lado, ROUSOU ${ }^{124}$, com experimentação em porcos, concluiu que cardioplegia sangüínea e cardioplegia cristalóide a $10^{\circ} \mathrm{C}$ conferem o mesmo grau de proteção miocárdica, e que a cardioplegia sangüínea intermitente a $30^{\circ} \mathrm{C}$ não protege o miocárdio de forma adequada, independentemente do nivel do hematócrito empregado. NOVICK et alii ${ }^{106}$ e SALERNO et alii ${ }^{126}$, também trabalhando com porcos com miocárdio hipertrófico, demonstraram que a soluçāo cardioplégica com fluosol a $20 \%$ e oxigenada foi superior à cardioplegia sangüínea e à cardioplegia cristalóide aerada.

Pela nossa experiência, a proteção miocárdica obtem-se com cardioplegia sangüínea contínua ou, melhor ainda, com cardioplegia sangüínea normotérmica e contínua ${ }^{83-85}$. Recentemente, um trabalho clínico de KHURI et alii ${ }^{65}$, da Harvard Medical School, relatando um método novo e muito sensível para avaliar o metabolismo miocárdico através da medida direta do $\mathrm{pH}$ tecidual, demonstrou a superioridade desse tipo de cardioplegia contínua em coraçōes hipertróficos.

É lógico que a cardioplegia contínua depende de acertos técnicos - que serāo discutidos mais adiante -e, quando não for possível fazê-la absolutamente contínua, que ela seja o menos descontínua possível. Outra vantagem da cardioplegia sangüínea é que podemos trabalhar com volumes muito maiores, uma vez que a diluição provocada no paciente é mínima, fornecendo-se cinco ou seis litros de cardioplegia por hora de clampeamento ${ }^{65}$, com apenas um litro de solução cristalóide concentrada adicionada ao sangue.

O agente que leva o coração à parada, seja na cardioplegia cristalóide ou sangüínea, pode ser potássio, magnésio, procaína ou, mesmo, quelantes e bloqueadores de cálcio, associados entre si ou não, e contando com a adição da hipotermia ou não ${ }^{15}$, 67, 139. A concentração de potássio na solução não deve exceder a 40
$\mathrm{mEq} / \mathrm{l}$ pois altera a membrana, permitindo a penetração de cálcio na célula, aumentando a demanda de energia $^{117}$.

\subsection{Resfriamento Cardíaco}

Caso optemos pelo resfriamento cardiaco, a temperatura do miocárdio deve ser baixada, esfriando a cardioplegia cristalóide, ou sangüínea, para 4 a $8^{\circ} \mathrm{C}^{46}, 121,124$. ${ }^{143}$. Estudos de BUCKBERG ${ }^{21}$ mostram a segurança da cardioplegia sangüínea a $8^{\circ} \mathrm{C}$. Porém, deve-se ficar atento para a falsa sensação de proteção a que a baixa temperatura pode nos induzir, uma vez que o frio, por si só, não é suficiente para manter o miocárdio viável por longos períodos.

Outro problema importante quanto ao frio relaciona-se ao funcionamento da bomba de cálcio, diminuindo sua performance e levando a aumento da tensão da parede, como já vimos anteriormente. Trabalhos recentes (1990) de LABOW et alii ${ }^{72}$ demonstraram que o frio diminui a função da Ca-ATPase, levando ao aumento de concentração do cálcio intracelular. Outros trabalhos de 1990 têm insistido em mostrar que a baixa temperatura leva ao menor relacamento diastólico ${ }^{56}$ e diminuição da função contrátil do coração transplantado, quando a temperatura fica abaixo de $6^{\circ} \mathrm{C}^{100}$. O coração parado a $22^{\circ} \mathrm{C}$ consome $0,3 \mathrm{ml}$ de $\mathrm{O}_{2}$ por $100 \mathrm{~g}$ de miocárdio/min, a $15^{\circ} \mathrm{C}$ tal consumo baixa apenas para $0,27 \mathrm{ml}$, mostrando que não existe muita vantagem em baixar a temperatura a niveis inferiores àqueles. A hipotermia de superfície ${ }^{50}$, embora atrapalhe tecnicamente $\mathrm{o}$ ato cirúrgico e não esfrie todas as camadas cardíacas com a mesma intensidade, pode ser um adjuvante de valor na proteção do coração, principalmente quando não se dá distribuiçăo perfeita da cardioplegia, como nos coronarianos, ou não se consegue canulação da coronária direita, nos aórticos ${ }^{20,26}$. A ação direta do frio sobre os nervos frênicos tem que ser lembrada, podendo levar a paralisia frênica transitória ou definitiva, no pós-operatório.

\subsection{Ressuscitação Cardíaca}

Desde 1982, ROSENKRANZ et alii ${ }^{120}$ criaram o conceito de ressuscitação cardiaca, que ficou mais evidente com o trabalho de BUCKBERG ${ }^{21}$, publicado em 1987 , empregando indução cardioplégica quente $\left(37^{\circ} \mathrm{C}\right)$ para melhorar o metabolismo cardiaco e as reservas miocárdicas de energia, antes do clampeamento aórtico.

Também o conceito de reperfusão assistólica modificada foi introduzida por LAZART et alii ${ }^{76}$, em 1979, sendo que, em 1986, ROSENKRANZ et alii ${ }^{12} 1$ demonstraram que, utilizando-se aspartato e glutamato na cardioplegia de reperfusāo durante o aquecimento, melhoravam ainda mais o metabolismo cardíaco. Em 1989, BUCKBERG $^{19}$ demonstra, de forma cabal, as vantagens da induçāo cardioplégica quente a $37^{\circ} \mathrm{C}$, assim como 
BRAILE, D. M.; ARDITO, R. V.; ZAIANTCHICK, M.; SANTOS, J. L. V.; SOARES, M. J. F. - Cardioplegia sangüinea continua normotérmica. Rev. Bras. Cir. Cardiovasc., 4(2): 109-138, 1989.

da reperfusão cardioplégica quente (na mesma temperatura), e ainda para os casos mais graves e com dificuldades para saída de circulaçāo extracorpórea, preconiza o emprego de outra reperfusão cardioplégica quente a $37^{\circ} \mathrm{C}$, com duração de até 20 minutos.

Utilizando toda esta metodologia, verificamos, ao longo dos últimos anos, as vantagens da induçăo cardioplégica a $37^{\circ} \mathrm{C}$ e a reperfusāo, também cardioplégica, na mesma temperatura. Ficou claro para nós que os pacientes mais graves, nos quais tal técnica era empregada, apresentavam melhor evolução, sendo facilmente retirados de by-pass ao final do procedimento.

Partindo destas observaçōes, seria fácil admitir que, se o coração fosse mantido "parado" e "perfundido" durante toda a cirurgia, mantendo-se a temperatura próxima do normal, o seu metabolismo seria conservado e as alterações metabólicas, minimizadas. Passamos a fazer induçāo quente $\left(37^{\circ} \mathrm{C}\right)$ em todos os pacientes e, gradativamente, subimos a temperatura de manutençāo, conservando-a entre $22^{\circ} \mathrm{C}$ e $25^{\circ} \mathrm{C}$, elevando-a a $37^{\circ} \mathrm{C}$ durante a reperfusão, com excelentes resultados. Coube, porém, a LICHTENSTEIN et alii ${ }^{83.85}$, do grupo de Thomas A. Salerno, de Toronto - Canadá, em 1989, criar um novo conceito em proteção miocárdica, mantendo o coração perfundido e parado em normotermia durante todo o período de clampeamento. Novos trabaIhos deste mesmo grupo, publicados por PANOS et alii $^{109,110}$, em 1990, têm demonstrado a superioridade do método sobre qualquer outro. Recentemente, SALERNO et alii ${ }^{126}$, utilizando a cardioplegia normotérmica contínua por via retrógrada, apresentaram resultados ainda superiores.

Esses trabalhos levaram-nos a modificar um pouco a técnica que empregávamos, continuando com a induçāo quente, seguida de manutençāo em normotermia (32 a $36^{\circ} \mathrm{C}$ ) de forma continua com baixo fluxo, ou com interrupções de 5-6 minutos e reperfusão de 2 minutos, quando necessário para facilitação da técnica. Modificamos, também, a dose de potássio da solução de manutenção, baixando-a para $10 \mathrm{mEq} / \mathrm{le}$ acrescentando magnésio, tanto na solução de indução como na de reperfusão. Ao final do procedimento, não dispensamos a reperfusão assistólica normotérmica. Existem algumas diferenças entre a proteçāo que temos realizado e aquela empregada pelo grupo de Toronto: a) temos feito indução cardioplégica quente com o uso de aminoácidos e substratos, para melhorar ou restaurar os niveis de ATP do coração, logo no início do clampeamento; b) mantendo o coraçāo perfundido (com baixo fluxo coronariano) durante a parada farmacológica em normotermia, buscamos manter o metabolismo de base funcionando, e este pode ser ainda melhorado se fornecermos substratos como glutamato, aspartato, etc.; c) durante a reperfusão assistólica, buscamos, mais uma vez, recuperar os déficits de energia, que, por acaso, tenham ocorrido durante a fase de manutenção por interrupçōes do fluxo de cardioplegia, para facilitar a técnica cirúrgica (achamos importante não estender esses períodos de isquemia além de 5-6 minutos). Fazemos a reperfusão final por 4 a 5 minutos, ou mais, se necessário, usando solução cardioplégica enriquecida com substratos em normotermia.

\subsection{Metabolismo Aeróbio e/ou Anaeróbio}

Substratos como glicose e oxigênio devem ser fornecidos durante o período de clampeamento aórtico, para garantir algum metabolismo aeróbio, nesse período.

Houve, no passado, muita discussăo a respeito do efeito deletério da glicose e da insulina na cardioplegia ${ }^{53}$. ${ }^{125}$, principalmente quando estudadas no coração isolado de ratos, sem a lavagem intermitente ou contínua dos catabólitos, que se acumulam com o metabolismo. Os resultados registrados por HEWITT et alii ${ }^{59} \mathrm{com}$ estudos in vivo, providenciando lavagem dos catabólitos, esclareceram o problema provando os efeitos benéficos da glicose e insulina.

Quando se usa cardioplegia sangüínea, os níveis de glicose do perfusato da circulação extracorpórea são, geralmente, suficientes para garantir um bom nivel de substrato. O oxigênio fornecido durante o estabelecimento da parada cardiaca e nas reperfusōes é mais do que suficiente para atingir o fim desejado. A adição de outros substratos precursores de intermediários do ciclo de Krebs, como o aspartato, o glutamato e o lactato, assim como o próprio fornecimento de ATP e/ou creatina fosfato (CP) podem melhorar muito a proteção miocárdica (Figura 1). Estes conceitos foram reforçados no Simpósio Internacional de Oxford para Preservação Mio-

\section{CICLO DE KREBS}

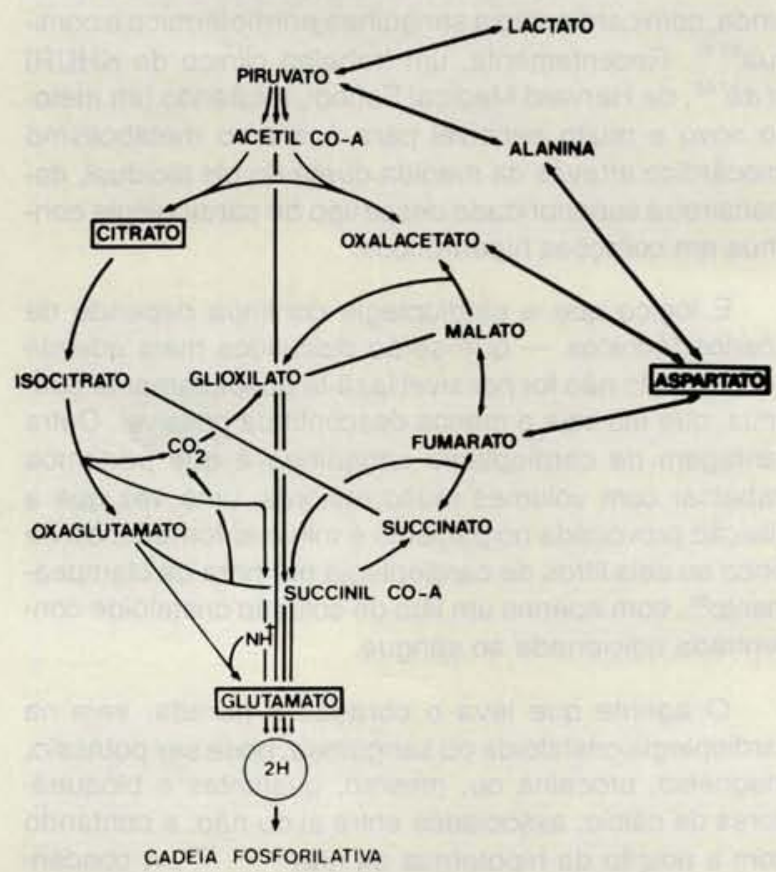

Fig. 1 - Representação esquemática do ciclo de Krebs. 
BRAILE, D. M.; ARDITO, R. V.; ZAIANTCHICK, M.; SANTOS, J. L. V.; SOARES, M. J. F. - Cardioplegia sangüínea contínua normotérmica. Rev. Bras. Cir. Cardiovasc., 4(2): 109-138, 1989.

cárdica no século XXI, com os trabalhos de STEINBERG et alii ${ }^{131}$, BOEHM et alii ${ }^{10}$ e THORELIUS et alii ${ }^{137}$. No caso de manter-se a cardioplegia normotérmica continua, o metabolismo básico é mantido e os substratos naturais do sangue e aqueles acrescentados são utilizados de forma adequada.

\subsection{Efeito Tampão}

O uso de tampões para minimizar os efeitos da acidose durante a isquemia é fundamental na manutenção dos metabolismos aeróbio e anaeróbio, além do funcionamento das bombas de sódio, potássio, cálcio e a integridade da membrana. É importante lembrar que, quanto mais baixa for a temperatura, maior deverá ser $0 \mathrm{pH}^{7}$.

Têm sido usados os mais diferentes tampões, como o bicarbonato de sódio, os tampões fosfato, o THAM, o imidazol ${ }^{142}$, e histidina ${ }^{69}$, ou o próprio sangue. Deverse-á selecionar o tampão que tiver maior poder tamponante na temperatura empregada. $O$ tampāo mais fácil de ser conseguido, em nosso meio, é o bicarbonato de sódio, utilizado na concentração de $5 \mathrm{mEq} / \mathrm{l}$ de cardioplegia, que não atende completamente o requisito a temperaturas baixas. BARNER ${ }^{4}$ mostrou as vantagens do sangue como tampão, não só com efeitos diretos sobre os ions hidrogênio, como também pela redução do $\mathrm{CO}_{2}$ via anidrase carbônica dos eritrócitos formando bicarbonato, mas também pela ação da hemoglobina, que desvia a reação para a direita, diminuindo a eventual acidose.

\subsection{Estabilização da Membrana}

Sem dúvida, a membrana celular, com todas as suas funçōes estruturais, seletivas e secretoras, é o ponto mais sensível à injúria isquêmica ${ }^{74}$.

A proteção do miocárdio é, em última análise, um conjunto de atitudes para conseguir-se a adequada proteção da membrana celular e seus "derivados", como a mitocôndria e o endotélio vascular. Tem sido demonstrado, por exemplo, que hipocalemia severa pode lesar definitivamente a membrana do sarcolema com morte celular $^{74,127}$. A lesão de reperfusão mediada pelo cálcio parece dependente da temperatura, como conclui o trabalho de HAMASAKI et alii ${ }^{52}$, que, estudando ratos, mostraram que a lesão é maior se a reperfusão for feita com niveis de calcemia acima de $0,7 \mathrm{mMol}$ a $37^{\circ} \mathrm{C}$. Contudo, se a temperatura de reperfusão for $20^{\circ} \mathrm{C}$, a recuperação do miocárdio independe da concentração do cálcio. Outra pesquisa, também feita em corações isolados de ratos, por BOGGS et alii ${ }^{11}$, do grupo de Daggett, mostrou que, se a soluçāo acalcêmica for oxigenada, há boa preservação do miocárdio, sendo os piores resultados obtidos com solução não oxigenada e com presença de cálcio. HENDREN et alii ${ }^{55}$, também do grupo de Daggett, registraram que a adição de $\mathrm{CO}_{2}$ elimina o paradoxo do cálcio, que também pode ocorrer se forem acrescentadas pequenas quantidades de cálcio ou sangue à solução cardioplégica.

Como já foi discutido anteriormente, a presença de altas quantidades de cálcio na solução cardioplégica aumenta o gasto energético pela maior tensão desenvolvida pela parede miocárdica, também decorrente da inibição da "bomba" de cálcio pelo frio, acidose, etc. TORCHIANA et alii ${ }^{138}$ demonstraram esta hipótese, recentemente, em corações de cães.

Com estes dados em mente, fica lógico o uso de quelantes de cálcio quando se emprega cardioplegia sangüínea. Sendo exemplos de uso prático: citrato fosfato dextrose ${ }^{43}$ (CPD) e bloqueadores de canais de cálcio, como verapamil ${ }^{149}$, nifedipina e diltiazem ${ }^{95,104}$. Estes têm-se mostrado úteis para a proteção do miocárdio, que sofre isquemia e reperfusão ${ }^{28,105}$. NAYLER ${ }^{103}$ mostrou o efeito protetor combinado da hipotermia e nifedipina em coraçōes de coelho.

Apesar dos trabalhos de HENRY et alii ${ }^{57}$ e de TAYLER et alii ${ }^{135}$ concluírem que há uma ação protetora pelo uso do diltiazem em injúria isquêmica, isto nāo foi possivel demonstrar em trabalhos de GREENFIELD et alii $^{49}$, em corações de ratos. Mais recentemente, contudo, uma série de trabalhos têm demonstrado que os bloqueadores de cálcio levam à melhor preservação miocárdica, durante e após a isquemia ${ }^{40,66,109}$

Há 5 anos, temos utilizado papaverina na dose de 5 a $10 \mathrm{mg}$ por litro de cardioplegia sangüínea como agente bloqueador de cálcio, entre outras propriedades, com bons resultados clínicos. A papaverina, além de produzir vasodilataçāo, é bloqueador de cálcio de curta duração ${ }^{60}$, inibidor da formação de íons superóxidos ${ }^{70}$ e bloqueador da degradação das purinas ${ }^{102}$, o que explica sua ação protetora, quando utilizada na cardioplegia de indução. A papaverina é um derivado do ópio, tem sido usada na prática médica por mais de 100 anos e não é tóxica, a menos que usada por longos períodos e em altas concentrações. Temos em curso um trabalho experimental em que comparamos a papaverina com outras drogas, na proteção contra a lesão de reperfusão regional, em miocárdio de carneiro submetido a isquemia e reperfusão, assim como em coraçōes isolados de coelhos. Outros autores têm demonstrado a ação benéfica da papaverina na cardioplegia ${ }^{64}$.

A utilização de corticosteróides e procaína para estabilizar a membrana tem sido controversa ${ }^{39}$, sendo que o corticóide parece aumentar o fluxo coronariano, o que não implica no aumento do fornecimento de oxigênio às células.

São protetores indiretos da membrana os removedores scavengers de radicais livres, como o superóxido desmutase (SOD), a catalase, a glutation peroxidase, o alopurinol, a vitamina E, a nicotinamida, o manitol, a coenzima Q10 deferoxamina e a própria papaverina. 
BRAILE, D. M.; ARDITO, R. V.; ZAIANTCHICK, M.; SANTOS, J. L. V.; SOARES, M. J. F. - Cardioplegia sangüinea contínua normotérmica. Rev. Bras. Cir. Cardiovasc., 4(2): 109-138, 1989.

Também o emprego de adenosina, que é um "antagonista natural" do cálcio e vasodilatador, leva a melhor recuperaçāo dos miocárdios isquêmicos.

\subsection{Hiperosmolaridade}

A solução cardioplégica tem que ser hiperosmolar, pois o edema acompanha o dano isquêmico dos tecidos. É lógico que o edema é a via final comum de todo o processo de alteração da membrana celular e do bloqueio da função metabólica. Usando-se um meio hiperosmolar, pode-se, pois, conseguir certa proteção. Contudo, se a solução cardioplégica for hiposmolar, a formação de edema surge, mesmo sem haver a intervenção desses mecanismos, mas pelo simples gradiente iônico transmembrana. Pode-se aumentar a osmolaridade das soluções ou sua pressão colóido-osmótica, para evitar tais conseqüências ${ }^{41}$. A osmolaridade não deve exceder $400 \mathrm{mOsm}$, surgindo, ao contrário, dano miocárdico mesmo sem isquemia ${ }^{146}$. O efeito do manitol não parece decorrer apenas de sua ação hiperosmolar, mas, principalmente, do efeito que tem como removedor (scavenger), por bloquear de forma direta os radicais oxidrila extremamente tóxicos para a matriz celular ${ }^{90,}{ }^{147}$.

\section{Uso de Removedores (Scavengers) na Cardioplegia}

Os trabalhos de McCORD \& FRIDOVICH ${ }^{92}$, em 1969, abrem o campo dos removedores, ou scavengers, com a descoberta da superoxidodesmutase (que contém cobre e zinco), dotada do poder de "desmutar" o superóxido em peróxido de hidrogênio, que é menos tóxico para as células. O peróxido de hidrogênio pode ser removido pela ação de outras duas enzimas, a glutation peroxidase e a catalase, com produçāo final de água. 0 superóxido, o ín oxidrila e o oxigênio atômico são todos muito tóxicos para as células e se formam pelo efeito do oxigênio durante a fase de reperfusão de tecidos isquêmicos ${ }^{132}$. Resultam da reação da xantina desidrogenase que, pela ação da isquemia, produz xantina-oxidase, que age sobre o substrato hipoxantina decorrente do metabolismo anaeróbio. Assim, podemos verificar que: 1) quanto maior for a quantidade de xantina desidrogenase que um tecido possui, maior será a quantidade de xantina oxidase produzida pela isquemia; 2 ) quanto maior a isquemia, maior será a produção de hipoxantina; 3) havendo muita hipoxantina e muita xantina-oxidase, na presença de oxigênio, formam-se grandes quantidades de radicais livres ${ }^{45}$.

Do ponto de vista prático, pode-se evitar a formação de radicais livres, eliminá-los ou impedir sua ação, diminuindo a quantidade de xantina-oxidase com o uso de alopurinol ou removendo-os com superoxidesmutase, catalase, peroxidase, manitol, vitamina $E$, etc. Com a perfusão contínua normotérmica, evita-se a isquemia e são fornecidos todos os removedores naturais, mesmo aqueles ainda desconhecidos.
O coração possui uma quantidade apreciável de xantina desidrogenase, de tal forma que estes mecanismos estão presentes durante a fase de reperfusão, após isquemia regional ou global. A seguinte cadeia de eventos seria a causa da lesão de reperfusão: 1) com introdução de $\mathrm{O}_{2}$ após isquemia, aparecem os radicais livres; 2 ) estes, pela degradação dos fosfolípides, produzem ácido aracdônio e levam ao aumento da ação do tromboxano $\mathrm{A}_{2}$ pelo bloqueio da síntese de prostaciclina; 3) surge espasmo coronariano, aumento da permeabilidade capilar, agregação e deposição de plaquetas, com liberaçāo de maiores quantidades do tromboxano; 4) enquanto o coração vai sendo aquecido, a microcirculação vai ficando parcialmente ocluída, resultando no fenômeno da "não reperfusão" tecidual (no reflow phenomena); 5) essa isquemia relativa, com o coração aquecido e na presença de oxigênio, leva à maior produção de radicais livres e conseqüente dano miocárdico; 6) aumento da permeabilidade ao ín cálcio, pela ação direta dos radicais livres sobre as fosfolipoproteínas da membrana, leva ao aumento do consumo e parada da produção dos fosfatos de alta energia e disfunção da mitocôndria.

Muitos trabalhos têm surgido para demonstrar os efeitos práticos da adição dos removedores à sistemática da cardioplegia. CHAMBERS et alii ${ }^{24}$ provaram, em 1987, a ação protetora do alopurinol e oxipurinol em corações de ratos submetidos a isquemia. VINTEN-JOHANSEN et alii ${ }^{143}$, trabalhando com cães, demonstraram também a melhora da ação da cardioplegia sangüinea com alopurinol. GREENFIELD et alii ${ }^{49}$, adicionando superoxidodesmutase e catalase à solução de St. Thomas, detectaram melhora significativa da proteção em coraçōes isolados de ratos, contra injúria por isquemia normotérmica e reperfusão. GHARAGOZLOO et alii ${ }^{48}$, do grupo de Cohn, empregando superóxido desmutase e catalase na solução cardioplégica, antes da reperfusão de uma área isquêmica em coraçōes de carneiros, obtiveram preservação da função contrátil e redução significante do tamanho da área do infarto (considerando as drogas para uso clínico). OTANI et alii ${ }^{108}$, do grupo de Engelman, usando corações isolados de suínos in situ, concluíram que o emprego do ácido nicotínico, antes da parada cardíaca, melhora a performance cardíaca, quando se compara com um grupo controle que não recebeu a droga. MENASCHE et alii ${ }^{98}$ utilizaram deferoxamina sistematicamente na solução cardioplégica em 24 pacientes e concluíram que esta droga, inibindo a produção de radicais livres mediada pelo ferro, diminui a resposta inflamatória à isquemia.

A partir de 1989, uma avalanche de trabalhos relacionados aos radicais livres e seus removedores têm tentado esclarecer três pontos básicos: a) se os radicais livres têm um papel importante na lesão de reperfusão; b) qual seria o mecanismo de ação dos radicais livres no coração; c) se os removedores têm, realmente, um papel protetor durante $a$ isquemia e a reperfusão e qual o momento ideal para sua introdução. 
BRAILE, D. M.; ARDITO, R. V.; ZAIANTCHICK, M.; SANTOS, J. L. V.; SOARES, M. J. F. - Cardioplegia sangüínea contínua normotérmica. Rev. Bras. Cir. Cardiovasc., 4(2): 109-138, 1989.

Tem sido possivel demonstrar que: a) os radicais livres têm um papel definido na lesão de reperfusão, podendo ser representados por radicais com núcleo de carbono ou nitrogênio, mas, principalmente, por aqueles derivados do oxigênio ${ }^{111}$. O seu local de atuação principal é a cadeia respiratória da mitocôndria com possibilidade da sua formação a partir de: 1) xantina oxidase, 2) leucócitos, 3) polimorfos nucleares ativados, 4) células endoteliais, 5) produtos da degradação dos fosfolipídios das membranas (ácido araquidônico) ${ }^{31}{ }^{113}$; b) quanto ao mecanismo e à fonte dos radicais livres durante a reperfusão miocárdica, não foi possivel, ainda, uma demonstração cabal $^{31}$. Parece que o endotélio vascular tem participação importante no processo; c) muitos trabalhos demonstram que os scavengers têm uma ação protetora definitiva para evitar a lesão de reperfusão, mesmo, muitas vezes, não se entendendo seu mecanismo de ação.

Há um grande número de substâncias que têm sido consideradas úteis no sentido de remover ou evitar a formação dos radicais livres, sendo, talvez, o assunto mais pesquisado, no momento. Apenas para que se tenha uma informação sobre as principais substâncias que têm sido estudadas ultimamente, relacionamos abaixo algumas delas e seus possiveis mecanismos de ação:

- Ceruplasmina: inibe a interação do radical livre com os lípides;

- Inibidores da enzima de conversão ${ }^{86}$ : reduzem os ácidos graxos não esterificados, incluindo palmítico, linoléico, oléico e araquidônico;

- T3, Fentolamina: têm-se mostrado úteis durante a reperfusão;

- Deferoxamina: mostrou bons resultados quando usada como pré-tratamento ${ }^{27,111}$;

- L-Propionilcarnitina: reduz a produçāo de radicais livres experimentalmente ${ }^{142}$;

- Catalase: mostrou proteção contra os efeitos dos radicais livres experimentalmente ${ }^{92}$;

- FBN (Fenilbutilnitrone): leva a proteção de coraçōes de ratos sujeitos a isquemia normotérmica, atuando como spin trap ${ }^{109}$;

- Captopril: reduziu a injúria de reperfusão, produzindo vasodilataçāo coronária e removendo radicais $\mathrm{OH}$ e $\mathrm{OCl}$ em corações de porcos ${ }^{35}$;

- Vitamina E (Tocoferol solúvel) com nome de Trolox e Vitamina C: têm-se demonstrado ativos na redução do dano miocárdico durante a reperfusão ${ }^{37}$;

- Alopurinol: não foi efetivo em modelos experimentais caninos ${ }^{62}$;

—SOD: conjugada com polietileno glicol: foi efetiva em coraçōes de coelhos ${ }^{116}$; SOD (recombinante) teve bom desempenho na proteção de coraçōes de hamster, adultos e neonatos, sendo a proteção dose-dependente. Do ponto de vista clínico, não foi, ainda, possível demonstrar o efeito de SOD.

Em nosso Serviço Experimental, estamos desenvolvendo um projeto, no qual se está testando o efeito protetor da deferoxamina e da papaverina na lesão de reperfusāo da isquemia regional em coraçāo de carneiro, além de outras substâncias que empregamos na preservação de coraçōes isolados de ratos e coelhos.

\section{Cardioplegia Retrógrada - Retroplegia}

Com o aumento do número de pacientes coronarianos e a possibilidade da revascularizaçāo miocárdica na fase aguda do infarto, surgiu novo interesse pela cardioplegia retrógrada. Isto ocorreu porque a retroplegia permite melhor distribuiçāo das soluçōes. O sistema venoso, não possuindo válvulas, permite a infusão retrógrada e, mesmo, áreas que não receberiam a cardioplegia, em decorrência das obstruçôes coronarianas, serão, certamente, protegidas quando a infusão for feita através do seio coronariano ou do átrio direito.

A indicaçāo da cardioplegia retrógrada também é vantajosa nos pacientes aórticos com óstios coronarianos de difícil acesso, nas dissecçōes agudas da aorta, ou em pacientes com insuficiência aórtica, que não permitam uma boa cardioplegia, mas que não tenham indicação absoluta para a troca valvar aórtica ${ }^{79}$. Temos empregado a retroplegia nos procedimentos sobre a válvula mitral, o que tem facilitado sobremaneira a manutenção de cardioplegia normotérmica contínua. Talvez a indicação de retroplegia mais importante e de maior impacto seja o seu emprego nas reoperaçōes de coronarianos, principalmente quando as pontes estão pérvias, mas apresentam lesões que contêm material pastoso, que pode, facilmente, produzir átero-embolização no leito natural, durante as manobras de dissecçāo ou cardioplegia anterógrada. Com a cardioplegia retrógrada, além de se evitar estes inconvenientes, ainda é possível "lavar" o sistema arterial de "trás para frente", limpando-o de possiveis materiais estranhos que tenham atingido a árvore coronariana. Esta tem sido nâo só a nossa experiência, mas também aquela de BUCKBERG ${ }^{19}$ e LOOP ${ }^{87}$. A perfusão cardíaca retrógrada já havia sido empregada por PRATT ${ }^{114}$, em 1898. Em 1948, BECK ${ }^{6}$ usou perfusão sangüinea retrógrada, num modelo experimental, demonstrando que não era suficiente para manter o coração trabalhando, porém chamou atenção para o assunto. Surgem, depois, os trabalhos de SOLORZANO et alii ${ }^{132}$, em 1978, e MENASCHÉ et alii ${ }^{97}$, em 1982, usando a perfusão retrógrada para indução e manutenção da cardioplegia. BOLLING et alii ${ }^{12}$, do grupo de Gott, mostraram a proteção do miocárdio pela perfusão retrógrada contínua de solução cardioplégica, estabelecendo o limite de $40 \mathrm{mmHg}$ como a pressāo ideal de infusão para 
BRAILE, D. M.; ARDITO, R. V.; ZAIANTCHICK, M.; SANTOS, J. L. V.; SOARES, M. J. F. - Cardioplegia sangüinea contínua normotérmica. Rev. Bras. Cir. Cardiovasc., 4(2): 109-138, 1989.

este tipo de técnica. Na literatura nacional, temos a destacar a tese de livre docência do Dr. Antônio de Pádua JAZBIK ${ }^{63}$ e a tese de doutorado do Dr. Rubens Ramos de ANDRADE $^{2}$, que ressaltam a validade do método. Mais recentemente, GUNDRY \& $\mathrm{KIRSH}^{51}$ mostraram a superioridade da distribuição da cardioplegia retrógrada distalmente a obstruçōes provocadas em coraçōes de cães. FABIANI et alii $^{37}$, do grupo de Carpentier, descreveram a técnica de cardioplegia retrógrada através do átrio direito, que leva à boa proteção do coração, sem qualquer lesão das câmaras direitas, apesar da distensão das mesmas, desde que a pressão de infusão não ultrapasse $40 \mathrm{mmHg}$.

Já empregamos esta técnica, que se mostra segura e útil, porém dificulta a operação nos doentes coronarianos e, mesmo, valvares, sendo inadequada para os congênitos em geral.

MENASCHÉ \& PIWNICA ${ }^{99}$, em 1987, descreveram uma cânula piriforme para ser usada diretamente no seio coronário e mostraram a experiência clínica com o método, que se demonstrava efetivo. BUCKBERG ${ }^{18}$, em1988, comentando o artigo de DIEHL et alii ${ }^{33}$, reafirma a idéia do uso concomitante de cardioplegia anterógrada e retrógrada para proteção adequada, rápida e uniforme do miocárdio isquêmico. Recentemente, repadronizou as técnicas de cardioplegia que emprega, dando grande destaque à retroplegia, que deve ser utilizada em conjunto com a cardioplegia anterógrada, levando a melhor proteção miocárdica. Buckberg também desenvolveu, em conjunto com o laboratório Shiley, uma cânula auto-inflável, que permite a retroplegia mesmo quando nāo se lançam as cavas e sem a necessidade de abrir o átrio direito, o que é mais uma grande contribuição deste grande pesquisador na área de proteção miocárdica ${ }^{19}$. A técnica para o emprego da cânula é simples, porém, sugerimos a leitura deste artigo, que apresenta em detalhes as diferentes táticas indispensáveis para sua utilização.

Desenvolvemos, em nosso grupo, uma cânula bastante simples constituída de sonda $16 \mathrm{~F}$ que tem em seu interior um cateter que ultrapassa na ponta (para medida de pressão). Na parte externa, a cânula apresenta um anel de silicone a $2 \mathrm{~cm}$ de sua extremidade, para auxiliar sua fixação no seio coronariano.

Para seu emprego, é necessário laçar as cavas e fazer uma bolsa de polipropileno $4-0$ nas bordas do seio coronariano, introduzindo-se a cânula sob visão e apertando-se a bolsa. Se este procedimento demanda algum tempo (2 a 3 minutos em média), assegura, por outro lado, a efetividade da retroplegia, que pode ser avaliada com segurança.

Mais recentemente, SALERNO et alii ${ }^{126}$ têm usado a retroplegia com sangue normotérmico como técnica exclusiva de proteção miocárdica, com resultados consistentes.
Acreditamos que o emprego da cardioplegia retrógrada deve crescer nos próximos anos, e lembramos apenas algumas das suas limitações: 1) a parada cardíaca nem sempre é imediata; 2) pode nāo ser eficaz para manter o coração protegido, se seu fluxo não for adequado, principalmente em casos de hipertrofia miocárdica severa, quando deve ser associada à cardioplegia anterógrada intermitente; 3 ) a proteçăo do ventrículo direito nem sempre é completa, pela perda de cardioplegia pelos vasos de Tebésio, e isto deve ser levado em consideração.

Parece-nos que a associação de cardioplegia anterógrada e retrógrada deve fazer parte das técnicas e táticas de proteção miocárdica. É indispensável permanente atenção à pressāo de infusão da cardioplegia no seio coronariano (nunca ultrapassando $40 \mathrm{mmHg}$ ), para a segurança do método.

\section{Reperfusão Assistólica}

É durante o período de reperfusão que o coração necessita: 1) recuperar os déficits de energia; 2) reparar os danos ocorridos durante a isquemia; 3 ) produzir energia para suportar a circulação.

Podemos atuar sobre os itens citados de tal forma a proteger o miocárdio nesta fase tão crítica e responsável pelo que se tem denominado de lesão de reperfusão. Na realidade, o coração, durante a isquemia, fica sensibilizado para sofrer a lesão tecidual que, de fato, vai ocorrer durante a reperfusão. A lesão de reperfusão pode ser evitada, mesmo no coração que sofreu isquemia severa, se as condiçōes e a composição do reperfusato forem modificadas.

O conceito de reperfusão assistólica modificada foi, inicialmente, descrito por LAZAR et alii ${ }^{76}$ (1979), do grupo de Buckberg. Os mesmos autores ${ }^{77}$, em 1980, ampliaram os efeitos protetores da reperfusão com a utilização de glutamato de sódio e conseguiram a reversão praticamente completa da lesão isquêmica, provocada em coraçōes de cães, por $\mathbf{4 5}$ minutos de isquemia normotérmica. Concluíram que soluçōes cardioplégicas contendo L-glutamato levam ao aumento de produção de ATP após a isquemia, estimulando o metabolismo oxidativo por fornecer intermediários do ciclo de Krebs perdidos durante a isquemia (Figura 2).

O mecanismo correto da ação do glutamato não é bem conhecido, porém, acredita-se que o mesmo entre nas reaçōes de transaminação para formar o alfa-cetoglutamato do ciclo de $\mathrm{Krebs}^{77}$. Os substratos podem ser, também, importantes fontes de energia via succinato no coração anóxico 8. 32, 59 . A publicação de ROSENKRANZ et alii ${ }^{120}$, em 1983, do grupo de Buckberg, introduziu o conceito de induçāo cardioplégica quente com adição de glutamato à solução de cardioplegia aquecida a $37^{\circ} \mathrm{C}$ para os casos de pacientes coronarianos em choque cardiogênico dependentes de drogas inotrópicas 


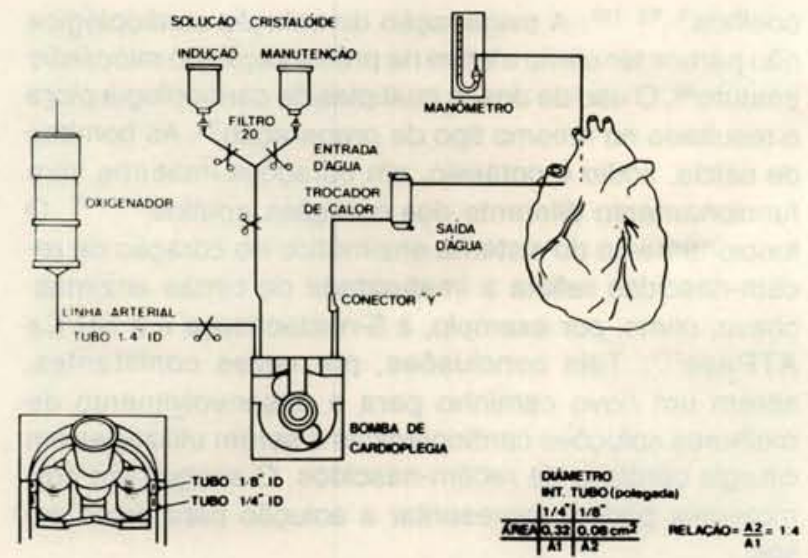

Fig. 2 - Representação esquemática do sistema usado para cardioplegia no IMC

e balâo intra-aórtico. O trabalho, baseado em experiências dos autores ${ }^{122 .}{ }^{123}$, permitiu demonstrar clinicamente resultados obtidos em experimentos, com diminuição da mortalidade operatória em um grupo de tão alto risco como o que foi citado. Em 1986, novamente ROSENKRANZ et alii ${ }^{121}$, estudando cães, conseguiram provar o efeito aditivo do uso de aspartato de sódio quando empregado em conjunto com o glutamato na solução cardioplégica. Os autores concluíram que o enriquecimento da soluçāo cardioplégica de glutamato com aspartato de sódio pode reverter o dano isquêmico miocárdico durante a reperfusāo, melhorando o metabolismo oxidativo neste periodo, e desenvolvendo trabalho cardiaco mais efetivo após a isquemia. Em 1978, HEARSE et $a^{2}{ }^{53}$, do grupo de Brainbridge, usando um modelo de coraçāo de rato, provaram que a adição de ATP e CP e uma solução cristalóide não oxigenada (St. Thomas) melhora a performance cardiaca após isquemia prolongada e que seus efeitos são somatórios.

Recentemente, TEOH et alii ${ }^{136}$, do grupo de Weisel, realizaram um trabalho clinico utilizando lactato marcado com carbono 14 (C14) e ventriculografia por técnicas nucleares, para demonstrar que o coração, após a parada cardioplégica, apresenta-se inábil para metabolizar ácidos graxos e glicose e que seu principal substrato é o lactato. Desta forma, utilizando Ringer lactato como soluçāo para o enchimento do sistema de extracorpórea e como solução de infusão durante o per-operatório, verificaram que: 1) o lactato foi o substrato preferido para o metabolismo oxidativo depois da parada cardiaca; 2) a maior concentração de lactato melhora a recuperação metabólica e funcional e reduz a lesão isquêmica per-operatória.

Baseados nestes dados experimentais e clínicos, uma boa parte destes substratos já estão em uso rotineiro, inclusive, como veremos a seguir, em nosso grupo, com resultados promissores ${ }^{14}$. Outros continuam em fase experimental ou em testes clínicos ${ }^{18}$. Alguns estudos experimentais têm mostrado que, mesmo a reperfusão assistólica sem modificação da composição do sangue tem um efeito protetor, preservando a função miocárdica e nāo levando a edema, como havia sido sugerido anteriormente ${ }^{1}$, sendo, portanto, um procedimento útil após a anóxia.

Ao término do período de isquemia, parece haver um desejo incontrolável para que o coração volte a bater imediatamente e que a circulação extracorpórea seja descontinuada ${ }^{81}$. A ação deletéria do uso de inotrópicos positivos para descontinuação precoce da circulação extracorpórea, levando a edema, diminuição da complacência ventricular e decréscimo da utilização de $\mathrm{O}_{2}$ pelo miocárdio, tem sido demonstrado na literatura ${ }^{75}$.

Parece-nos que o momento da reperfusão é o mais importante da proteçāo miocárdica, reperfundindo o coração com cardioplegia aquecida, enriquecida com substratos e contendo quelantes e/ou bloqueadores de cálcio; durante cinco minutos, ocorre recuperação funcional do miocárdio severamente lesado pela isquemia. O tempo de reperfusão assistólica pode ser prolongado até 20 minutos, quando necessário (para recuperar grandes déficits de energia).

Gostaríamos de reafirmar o conceito emitido por BUCKBERG ${ }^{20}, 21$, de que o tempo é mais importante do que a dose de solução cardioplégica, pois o coração consome oxigênio por minuto e não por $\mathrm{ml}$ de solução infundida, devendo-se, portanto, basear a reperfusão pelo tempo que a empregamos e não pelos volumes de reperfusato. É durante o período de reperfusão que ocorre a liberação dos radicais livres e, como vimos anteriormente, o uso de removedores (scavengers) destes radicais, nesse período, pode melhorar as condições e o resultado da reperfusão. Essa técnica, com a adição da retroplegia, tem sido empregada, recentemente, por BUCKBERG $^{19}$ e por seu grupo ${ }^{112}$. Como veremos, tem sido esta, também, nossa conduta; mesmo quando utilizamos a cardioplegia normotérmica contínua, não deixamos de fazer uma reperfusão assistólica com cardioplegia sangüinea modificada com glutamato, aspartato, etc.

\section{Indução Cardioplégica Quente}

Quando nos defrontamos com casos extremamente graves por disfunção muscular, ou nos quais existe isquemia miocárdica severa em conseqüência de choque cardiogênico, infarto miocárdico em curso, ou instabilidade hemodinâmica, antes da instalação da circulação extracorpórea, está indicado o início de infusão de cardioplegia sangüínea oxigenada em normotermia enriquecida com substratos, mesmo antes do pinçamento aórti$c o$, para que não se perca qualquer tempo durante a instalação da cardioplegia.

Pinçada a aorta, continua-se a infusão cardioplégica por 5 minutos a $37^{\circ} \mathrm{C}$, de tal forma a reparar os danos da isquemia e fornecer energia ao miocárdio, que agora está em repouso e recebendo oxigênio e substratos ${ }^{21}$. 
BRAILE, D. M.; ARDITO, R. V.; ZAIANTCHICK, M.; SANTOS, J. L. V.; SOARES, M. J. F. - Cardioplegia sangüínea contínua normotérmica. Rev. Bras. Cir. Cardiovasc., 4(2): 109-138, 1989.

\subsection{Ressuscitação Cardiaca}

Os primeiros trabalhos visando à ressuscitaçāo cardiaca datam de 1982, quando ROSENKRANZ et alii ${ }^{120}$ criaram este conceito, completando-se com trabalhos subseqüentes do mesmo grupo ${ }^{19,} 21,112,121$.

É importante enfatizar, novamente, que o tempo de indução da cardioplegia sangüina oxigenada é mais importante que a sua dose, pois o miocárdio gasta, ou melhor, aproveita oxigênio por minuto e não por litro.

O coração normal parado em normotermia consome $1 \mathrm{ml}$ de $\mathrm{O}_{2}$ por $100 \mathrm{~g}$ de músculo cardiaco por minuto, porém o miocárdio depletado de energia consome 5 a $6 \mathrm{ml}$ de $\mathrm{O}_{2}$ por minuto. A infusão de cardioplegia sangüinea oxigenada durante 5 minutos fornecerá 25 a $30 \mathrm{ml}$ de $\mathrm{O}_{2}$ para o coraçāo, restaurando suas reservas de energia ${ }^{21}$. Tem importância, nesse período, o controle rigoroso do fluxo e da pressão empregada na infusão das soluçōes cardioplégicas. Assim, o conceito de proteção miocárdica por cardioplegia fica estendido de tal forma que as soluçōes cardioplégicas oxigenadas e modificadas levam a: 1) ressuscitação ativa do miocárdio; 2) prevençāo e reversão da lesão isquêmica; 3 ) prevenção e reversão da lesão de reperfusão.

A ressuscitação ativa do miocárdio está indicada também nos casos que, por qualquer motivo, não receberam boa proteção durante a fase de isquemia e/ou reperfusão. São pacientes que não conseguem manter-se em condiçōes hemodinâmicas aceitáveis após a cessação da circulação extracorpórea; nestes casos, deve-se retornar ao auxílio circulatório, pinçar a aorta e reinfundir cardioplegia sangüínea oxigenada por 5 a 10 minutos, mantendo-se o paciente em extracorpórea por mais 10 a 15 minutos, descontinuando-a, a seguir. Em geral, com este novo aporte de energia, o coração volta a funcionar adequadamente e pode suportar a circulação. Sendo a indução quente de valor indiscutível para os casos graves, teria que ser também útil nos casos rotineiros; isso nos levou a empregá-la em todos os pacientes, com excelentes resultados, sem acrescentar qualquer inconveniente maior.

\subsection{Descompressão Cardiaca}

BUCKBERG ${ }^{21}$ recomenda que o coração tenha sempre suas câmaras drenadas, evitando-se qualquer aumento na tensāo da parede, que levaria a maior consụmo de $\mathrm{O}_{2}$ Trabalhos experimentais recentes têm, contudo, demonstrado que pressões de até $15 \mathrm{mmHg}$ no ventrículo esquerdo não afetam a recuperação funcional do miocárdio ${ }^{73}$ e podem até ser benéficas.

\section{Situaçōes Especiais}

1) O miocárdio imaturo parece ser mais resistente à isquemia quando se trabalha com coração isolado de coelhos $^{3 .}$ 53, 116 . A oxigenação de solução cardioplégica não parece ter efeito efetivo na preservação do miocárdio imaturo ${ }^{88}$. O uso de doses múltiplas de cardioplegia piora o resultado no mesmo tipo de preparaçăo ${ }^{89}$. As bombas de cálcio, sódio e potássio, em corações imaturos, têm funcionamento diferente dos corações adultos ${ }^{115,}{ }^{129}$. O funcionamento do sistema enzimático no coração de recém-nascidos reflete a imaturidade de certas enzimaschave, como, por exemplo, a 5-nucleotidase e a SR Ca ATPase $^{117}$. Tais conclusōes, por vezes conflitantes, abrem um novo caminho para o desenvolvimento de melhores soluções cardioplégicas a serem utilizadas em cirurgia cardiaca de recém-nascidos. O sangue em normotermia poderá representar a solução para estes casos.

2) Miocárdio cianótico: o metabolismo e, principalmente, a resistência à isquemia, que já se pensou fosse maior nos corações de pacientes cianóticos, tem-se demonstrado, pelo contrário, menor. Assim, os trabalhos de SILVERMAN et alii ${ }^{129}$, do grupo de Levitsky, indicam que a hipoxemia crônica leva a déficit contrátil pós isquemia por depleção acelerada dos fosfatos de alta energia durante a isquemia. Recentemente, em trabalho experimental desenvolvido em carneiros cianóticos (por anastomose da aurícula esquerda com a artéria pulmonar), FUJIWARA et alii ${ }^{46}$, do grupo de Mayery, demonstraram que coraçōes neonatais de animais cianóticos são mais vulneráveis à isquemia, sendo que a cardioplegia melhora a função sistólica, mas não a função diastólica desses ventrículos. Demonstraram, também, que a participação dos radicais livres pelo efeito tóxico do oxigênio durante a reperfusão dos cianóticos deve ter papel importante no desenvolvimento da lesão miocárdica deste grupo.

3) Miocárdio hipertrófico: os coraçōes hipertróficos representam o verdadeiro desafio para o teste das soluções cardioplégicas, já que apresentam alto consumo de energia, que, uma vez interrompida, leva a lesões muito graves. Durante a isquemia, o coração hipertrófico deve ser parado imediatamente ${ }^{129}$, fornecendo-se, além disto, substrato. Também soluções oxigenadas e, principalmente, quando contém fluosol em sua composição, levam a melhor proteção dos coraçōes hipertróficos, como mostra o trabalho experimental de NOVICK et alii ${ }^{106}$ e SALERNO et alii ${ }^{126}$. A cardioplegia sangüinea oxigenada, enriquecida com substratos, contínua por via anterógrada e retrógrada, tem-se demonstrado eficaz na preservação do miocárdio hipertrófico, mesmo quando apresenta disfunção acentuada antes da isquemia ${ }^{65}$.

4) Miocárdio infartado: aplicam-se, aqui, os conceitos de ressuscitação cardíaca, lembrando-se que a área infartada dificilmente é atingida pela cardioplegia anterógrada, sendo uma excelente indicaçāo para a indução e manutenção quente anterógrada e retrógrada, de tal forma que os benefícios de cardioplegia possam atingir a área em risco ${ }^{133}$. O uso de substratos ${ }^{21}$ e drogas bloqueadoras dos canais de cálcio tem demonstrado sua 
BRAILE, D. M.; ARDITO, R. V.; ZAIANTCHICK, M.; SANTOS, J. L. V.; SOARES, M. J. F. - Cardioplegia sangüínea contínua normotérmica. Rev. Bras. Cir. Cardiovasc., 4(2): 109-138, 1989.

eficácia na redução dos infartos em evolução ${ }^{95}$. Outras técnicas têm sido empregadas para melhorar a difusão da cardioplegia ou do reperfusato, durante a reperfusão das áreas isquêmicas, como sejam: a) oclusão intermitente do seio coronariano com sigla em inglês PICSO (Pressure Controled Intermittent Coronary Sinus Occlusion), que, segundo o trabalho de LAZAR et alii ${ }^{78}$, efetivamente reverte a lesão de reperfusão após períodos de isquemia, podendo auxiliar no manuseio de pacientes revascularizados durante o infarto agudo; b) infusão anterógrada continuada com oclusão do seio coronário, de forma a obter-se uma pressāo máxima de $50 \mathrm{mmHg}$ no sistema venoso, perfundindo áreas isquêmicas por via retrógrada. Esta técnica foi proposta por SUN et alii ${ }^{133}$, TABAYASHI et alii ${ }^{134}$, que, usando carneiros como modelo experimental, puderam demonstrar melhor proteção global e regional do miocárdio, quando uma artéria coronária era ocluída e a infusāo cardioplégica anterógrada, combinada com hipertensão do sistema venoso coronariano, através de ligadura provisória do seio coronário.

Recentemente (1989 e 1990), BUCKBERG ${ }^{19}$ e PRA$S A D^{11}$ mostraram mortalidade de apenas $2,5 \%$ em pacientes coronarianos com infarto do miocárdio em evolução, ou fração de ejeção menor que 0,20 , tratados com revascularizaçāo do miocárdio, usando enxertos venosos para as artérias das regiōes infartadas e realizando cardioplegia anterógrada e retrógrada, com indução quente e reperfusão assistólica modificada.

Fica claro, portanto, que a técnica e a tática empregadas em cada caso são fundamentais para os bons resultados, os mínimos detalhes devem ser observados e as regras, seguidas rigorosamente.

\section{Pontos Básicos}

São pontos básicos para a proteçāo e recuperação do miocárdio em risco:

1) Uso de cardioplegia sangüínea modificada e controlada em: a) indução quente $36^{\circ} \mathrm{C}$ - para recuperar os déficits de energia; b) manutenção aquecida 32 a $36^{\circ} \mathrm{C}$ - fazendo a cardioplegia modificada fluir pelo sistema coronariano, de forma contínua, com baixo fluxo, garante-se a parada cardíaca e o metabolismo básico é mantido ativado com produção de energia para preservação da integridade dos tecidos; c) reperfusão quente $36^{\circ} \mathrm{C}$ - mesmo considerando o período de manutenção adequado, pode ocorrer algum dano ou déficit de energia, que será restaurado neste período, com o uso de solução cardioplégica modificada, dando um "descanso" adicional ao coração.

2) Manutençăo de suporte circulatório adequado até a recuperação funcional do miocárdio, permitindo estabilização hemodinâmica completa.

\section{Pontos de Investigação}

1) A utilização de removedores de radicais livres efetivos, durante as 3 fases do processo de proteçāo miocárdica, poderá ser muito benéfica. $O$ futuro deverá contar com tais removedores com a propriedade de ganhar, rapidamente, o interior das células e os espaços perivasculares, tornando-se, assim, extremamente úteis.

2) O edema, durante a reperfusão, representa um grande problema, principalmente quando ocorre em decorrência de injúria miocárdica. Os agentes osmóticos ativos, com que contamos atualmente, são inadequados pelo seu pequeno tamanho molecular e discreta capacidade de ter acesso ao espaço intersticial. Agentes osmóticos ativos que impermeabilizam o endotélio deverāo estar disponíveis no futuro, evitando, definitivamente, 0 edema.

3) Atualmente, a parada cardíaca tem sido conseguida por despolarização da membrana, o que leva à anormalidade significante do fluxo eletrolítico. Agentes químicos "polarizantes" que bloqueiam de forma específica e seletivamente canais de sódio, estarão disponíveis dentro em breve e a parada cardíaca por "atordoamento" será conseguida. A influência da polarização celular nas suas capacidades sintetizantes necessitará, contudo, de avaliação.

4) Embora tenha sido demonstrado que a adiçāo de glutamato e aspartato melhora o metabolismo celular, o refinamento do suporte metabólico será feito com a utilização de agentes que sejam mais interativos com os fosfatos de alta energia, ou possam prover substratos para a geração de fosfato de alta energia de forma continua e eficaz.

\section{Técnica Cardioplégica IMC}

Apresentaremos, agora, o método de proteção miocárdica que tem sido empregado no IMC (Instituto de Moléstias Cardiovasculares em São José do Rio Preto, SP).

Iniciamos a utilização da cardioplegia de forma pioneira em setembro de $1973^{14}$ e, deste então, temos utilizado esta técnica em todos os casos por nós operados. Ao longo do tempo, muitas modificaçōes foram introduzidas pelos conhecimentos da literatura e pela experiência adquirida. Ultimamente, os processos de proteção miocárdica têm evoluído de forma ainda mais rápida, levando à incorporaçāo de técnicas que são conceitualmente diferentes das utilizadas anteriormente. Assim, mais recentemente, temos trabalhado com temperaturas mais altas, utilizando potássio em concentração (24 $\mathrm{mEq} / \mathrm{l})$ para o período de indução inicial e $10 \mathrm{mEq}$ para período de manutençāo e reperfusāo. Passaremos a descrever nossa conduta prática atual, que acreditamos ser útil para todos aqueles que se dedicam à cirurgia cardiaca. 
BRAILE, D. M.; ARDITO, R. V.; ZAIANTCHICK, M.; SANTOS, J. L. V.; SOARES, M. J. F. - Cardioplegia sangüínea contínua normotérmica. Rev. Bras. Cir. Cardiovasc., 4(2): 109-138, 1989.

Como já dissemos, desde 1973 estamos empregando cardioplegia em nosso Serviço. Durante todos esses anos, as técnicas foram modificadas evolutivamente, iniciando-se com Ringer lactato acrescido de potássio e chegando à cardioplegia sangüínea contínua normotérmica enriquecida com aminoácidos.

Queremos salientar que a efetividade da cardioplegia é relação direta da determinação que temos ao realizá-la e decorrente da técnica empregada quando as bases fisiológicas obedecem a critérios já provados e estabelecidos. Conceitualmente, seria ideal que o coração pudesse ser operado sem que ocorresse isquemia nos seus tecidos.

No sentido de elimınar os transtornos causados pelos batimentos cardiacos e o campo inundado de sangue, optamos pela cardioplegia sangüínea modificada, normotérmica e contínua (sempre que possível).

A técnica cirúrgica tem que ser adaptada, para que a cardioplegia seja efetiva e não represente um transtorno adicional para a realizaçāo do ato operatório.

Lembramos, também, que a função principal do cirurgião é operar o paciente e que a correçāo anatômica dos defeitos é fundamental para o sucesso cirúrgico, sendo a proteção miocárdica e a ressuscitação cardíaca apenas auxiliares do processo.

\subsection{Técnica Cirúrgica para Casos Convencionais}

Após realizaçāo de esternotomia mediana, instalamos a circulação extracorpórea por canulação das cavas, ou do átrio direito, e da raiz da aorta. Introduzimos um cateter no átrio esquerdo através da veia pulmonar superior direita para monitorização da pressão do átrio esquerdo (PAE). Antes do pinçamento aórtico, colocamos, através de uma bolsa de Prolene 3-0, uma cânula metálica $12 \mathrm{~F}$ especialmente desenvolvida, na aorta abaixo da área de pinçamento, para injeçāo da cardioplegia. Utilizamos um "jelco" 14F introduzido em separado com outra bolsa de Prolene 4-0 para medida da pressẫo da raiz da aorta e alívio das cavidades esquerdas, quando necessário. Monitoramos a temperatura do septo com sensor de agulha introduzido no local. Este sensor, devido às dificuldades de importação, alto custo e problemas de manutenção, foi desenvolvido em nosso grupo na esperança de contribuir para a segurança da proteção miocárdica, em nosso meio (termômetro IMC-BIO modelo AG-100).

\subsubsection{Indução}

Iniciamos a injeção da cardioplegia antes do pinçamento aórtico, que é realizado logo a seguir. A indução é feita durante 4 ou 5 minutos, mantendo-se 50 a 60 $\mathrm{mmHg}$ de pressão na raiz da aorta, até parada completa dos batimentos cardíacos e obtenção de uma tempe- ratura do septo que esteja entre $30^{\circ} \mathrm{C}$ e $36^{\circ} \mathrm{C}$. Monitoramos a PAE nunca permitindo elevação acima de 10 $\mathrm{mmHg}$. É importante notar, também, que utilizamos a solução de indução (24 mEq de potássio/l) apenas para a parada completa dos batimentos cardiacos empregando-se, para isto, cerca de 100 a $200 \mathrm{ml}$ da soluçāo mãe de indução (dependendo do tamanho do coração). Uma vez obtida a parada cardiaca, continuamos o período de induçāo de cardioplegia utilizando solução de manutenção-reperfusão (10 mEq de potássio/l) até completar o tempo de indução (que é de 4.5 minutos), podendo, até, ser prolongado em casos mais graves.

Não nos temos preocupado com o volume e sim com o tempo de injeção de cardioplegia, que já se demonstra ser mais importante. Exceção é feita para os casos de crianças de baixo peso e neonatos, nos quais temos um limite para os volume infundidos, como veremos à frente. Durante esse período, certos procedimentos cirúrgicos podem ser realizados, desde que não ocorra distorção da aorta, ou dificuldade técnica.

\subsubsection{Manutenção}

Terminada a fase de induçāo, passamos à fase de manutenção da cardioplegia com o emprego da solução de manutenção-reperfusão. Nessa fase, a infusão da cardioplegia será realizada de forma contínua ou com interrupções curtas (5 minutos) durante os "tempos" da cirurgia que estamos realizando. Durante injeçāo da soluçāo, a pressāo da raiz da aorta é constantemente monitorizada e mantida entre $20-50 \mathrm{mmHg}$, assim como a pressão do átrio esquerdo, que é mantida abaixo de $10 \mathrm{mmHg}$. Se a pressão do átrio esquerdo eleva-se ou o ventrículo esquerdo distende-se, drenamos esse ventrículo com introdução de um aspirador na forma de uma sonda metálica multiperfurada de calibre 12F (aspirador de ponta de VE IMC-BIO). O fluxo da cardioplegia de manutenção-reperfusão deve ser de 50 a $150 \mathrm{ml}$ da solução final por minuto (10 a $30 \mathrm{ml}$ da soluçao mãe por minuto), observando-se a pressão da raiz da aorta e, se possível, o efluente do seio coronário ou dos ósteos coronarianos (no caso da cardioplegia retrógrada) quanto à saturação de $\mathrm{O}_{2}$. Caso esta esteja muito baixa, é sinal de que necessitamos de maior fluxo. A observação do sistema venoso durante a cardioplegia anterógrada é um bom indicador do fluxo efetivo da solução; caso as veias mostrem-se de coloração escura, isto significa que o fluxo efetivo da cardioplegia deve ser aumentado; no caso da retroplegia, o efluente pelas arteriotomias podem dar a mesma indicação. Após qualquer interrupção da cardioplegia, devemos reperfundir o miocárdio pelo menos durante dois minutos, até a nova parada da infusāo.

Sāo sinais importantes que indicam necessidade de repetição da cardioplegia de manutenção, ou mesmo da cardioplegia de induçăo, o aparecimento de batimentos cardíacos e/ou atividade elétrica no cardioscópio (se o coração persiste em bater durante o período de manu- 
BRAILE, D. M.; ARDITO, R. V.; ZAIANTCHICK, M.; SANTOS, J. L. V.; SOARES, M. J. F. - Cardioplegia sangüinea contínua normotérmica. Rev. Bras. Cir. Cardiovasc., 4(2): 109-138, 1989.

tenção, injetamos 20 a 50 ml da solução mãe de indução, até obter nova parada de batimento).

Ao final do procedimento, antes do despinçamento aórtico, fazemos a cardioplegia aquecida de reperfusão (soluçāo de manutenção-reperfusão), durante 4 ou 5 minutos com o coração parado, elevando a temperatura do septo a $34-36^{\circ} \mathrm{C}$, quando, então, desclampeamos a aorta usando a cânula de cardioplegia e da pressão de raiz, para aspiração do ar que, eventualmente, possa encontrar-se do lado esquerdo do coração. $O$ fluxo de solução cardioplégica final durante a reperfusão é de 200-300 ml por minuto ( 40 a $50 \mathrm{ml}$ da solução mãe) observando-se a pressão da raiz da aorta, que não deve exceder $59-60 \mathrm{mmHg}$. Essa reperfusāo pode se prolongar até 20 minutos, em casos especiais. Os fluxos indicados para indução, manutenção e reperfusão são aproximados. Consideramos da maior importância a observação da pressão da raiz da aorta, sua relação com o fluxo da cardioplegia e os tempos empregados em cada etapa. Como já dissemos, a saturação venosa do sistema coronariano poderá orientar-nos de forma muito adequada quanto à efetividade do fluxo. A observação das veias do coração sempre nos dará uma idéia do consumo de $\mathrm{O}_{2}$ pelo miocárdio e do equilibrio entre oferta e demanda. Durante as reperfusōes, também nos orientam se a deficiência de oxigênio já foi compensado. Após o desclampeamento, a pressão sistêmica é mantida em torno de $50 \mathrm{mmHg}$, por 2 ou 3 minutos. Em geral, o coração volta a bater espontaneamente, depois de 20 a 60 segundos, sendo muito raro ocorrer fibrilação ventricular (menos de $1 \%$ dos casos). Os batimentos, de início, são lentos, mostrando no monitor sinais de hiperpotassemia, que logo desaparecem, surgindo ritmo sinusal regular sem alterações da condução e repolarização. Aguarda-se a estabilização hemodinâmica continuandose a monitorização da pressão da raiz da aorta (que é muito mais fidedigna que a pressão da artéria radial) e pressōes do átrio esquerdo e direito. Se for conveniente pode-se injetar por via venosa 5 a $10 \mathrm{ml} \mathrm{de} \mathrm{CaCl}_{2}$ após
7 a 10 minutos do desclampeamento quando o coraçāo já apresenta batimentos normais. Uma vez estabilizado o quadro hemodinâmico, interrompe-se a circulação extracorpórea, o que ocorre cerca de 10 minutos após o desclampeamento aórtico. Injeta-se protamina pela cânula de pressão de raiz da aorta ou do átrio esquerdo, faz-se revisāo da hemostasia e fechamento por planos.

\subsection{Soluções}

A proteção miocárdica é realizada por cardioplegia sangüinea i portanto, utilizamos sangue modificado com diversos componentes, resultando na cardioplegia sangüínea modificada. Por isto, do ponto de vista prático, temos que dispor de: 1) sangue - retiramos do depósito do oxigenador ou da sua linha arterial. Este é o sangue que de qualquer forma irá perfundir as coronárias, o cérebro etc., com a aorta pinçada ou despinçada. $\mathrm{O}$ sangue da linha arterial deverá estar livre de qualquer partícula maior que as malhas do filtro empregado, para que a CEC e a perfusão coronariana sejam seguras; 2) diluidor - é uma bomba de CEC que permite diluir os "componentes da solução mãe" no sangue que retiramos do oxigenador. No nosso caso, fazemos diluição dos componentes na proporção de $1: 4$, utilizando uma bomba de roletes que tem dois tubos na mesma unidade: um de $1 / 8$ " e outro de $1 / 4$ ", de tal forma que, sempre que o primeiro bombear uma determinada quantidade, o outro terá bombeado uma quantidade quatro vezes maior. Assim, teremos sempre uma parte de "componentes da solução mãe" em quatro partes de sangue; 3) soluções "mãe" - os "componentes" da cardioplegia estão contidos em soluçōes "mãe" que chamamos de: solução de indução (Tabela 1) e solução de manuteção-reperfusão (Tabela 2):

Para maior facilidade, desenvolvemos um kit para cardioplegia de indução, que contém todos os "compo-

TABELA 1

COMPONENTES DA SOLUÇĀO CARDIOPLÉGICA DE INDUÇĀO NORMOTÉRMICA USADA NO IMC, E SEUS RESPECTIVOS VOLUMES E CONCENTRAÇÓES.

\begin{tabular}{|c|c|c|c|c|}
\hline \multicolumn{3}{|c|}{ Componente } & \multirow{2}{*}{ Volume (mI) } & \multirow{2}{*}{$\begin{array}{c}\text { Concentração final diluída } \\
1: 4 \text { com sangue }\end{array}$} \\
\hline Adicionado & & Sanguineo modificado & & \\
\hline Soro glicosado $5 \%$ & & Osm substrato & 390 & $340-360 \mathrm{mOsm}$ \\
\hline ACD* & & $<\mathrm{Ca}++$ & 30 & $0,5-0,6 \mathrm{mM} / \mathrm{l}$ \\
\hline Cloreto de potássio & $19,1 \%$ & $\mathbf{K}+$ & 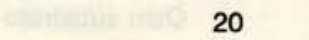 & 22 a $24 \mathrm{mE} / \mathrm{I}$ \\
\hline Bicarbonato de sódio & $8,4 \%$ & $\mathrm{pH}$ & 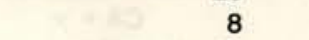 & $7,5-7,6$ \\
\hline Sulfato de magnésio & $10 \%$ & $\mathrm{Mg}++$ & $\sqrt{2}+2$ & 4,4 a $5,2 \mathrm{mEq} /$ \\
\hline Insulina simples & & substrato & 10 un & $2,0 \mathrm{U} / \mathrm{I}$ \\
\hline Papaverina & & $<\mathrm{Ca}++$ & 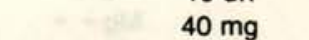 & $8 \mathrm{mg} / \mathrm{l}$ \\
\hline Glutamato de sódio & & substrato & 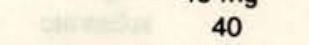 & $12 \mathrm{~m} \mathrm{~mol} / 1$ \\
\hline Aspartato de sódio & & substrato & 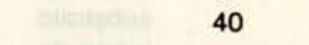 & $12 \mathrm{~m} \mathrm{~mol} / \mathrm{l}$ \\
\hline
\end{tabular}

'ACD = ácido citrico, citrato de sódio e dextrose.

"Ajinomoto Co., Inc. Tokio, Japâo. 
BRAILE, D. M.; ARDITO, R. V.; ZAIANTCHICK, M.; SANTOS, J. L. V.; SOARES, M. J. F. - Cardioplegia sangüinea contínua normotérmica. Rev. Bras. Cir. Cardiovasc., 4(2): 109-138, 1989.

Desenvolvemos um kit"." para cardioplegia de inducáo, que é constituido por 4 trascos, conforme especificaçáo abaixo, bastando adicioná-los em $370 \mathrm{ml}$ de soro glicosado para obler a composicáo adequada: 1 frasco de solucáo de induça - 1 (papaverina) (A): 1 frasco de soluçáo de induçäo - 1 (ácido citrico, citrato de sódio, dextrose, cloreto de potássio, sulfato de magnésio) (B); 1 frasco de soluçáo de induçáo - 1 (bicar. bonato de sódio) (C); 1 frasco de soluçäo (glutamato, aspartato) (D).

Acrescentar 10 unidades de insulina simples, a qual nảo acompanha o kit, por ser conservada refrigerada.

Seqüéncia a ser usada ao adicionar os frascos ao soro glicosado $5 \%$ : $A+B+C+D$. Caso esta seqüéncia nāo for obedecida, ocorrerá a precipitaçâo de cartononato de magnésio $\left(\mathrm{MgCO}_{3}\right)$ insolúvel no meio: $\mathrm{Mg}^{+2}+\mathrm{CO}_{3}^{2} \longrightarrow \mathrm{MgCO}_{3}$

TABELA 1 (Continuaçāo)

\begin{tabular}{lr}
\hline \multicolumn{2}{c}{$A$} \\
\hline Papaverina & $0,04 \mathrm{~g}$ \\
Excipiente q.s.p. & $10 \mathrm{ml}$ \\
\hline
\end{tabular}

\section{B}

\begin{tabular}{lr}
\hline Ácido cítrico & $0,132 \mathrm{~g}$ \\
Citrato de sódio & $0,396 \mathrm{~g}$ \\
Dextrose & $0,441 \mathrm{~g}$ \\
Cloreto de potássio & $50 \mathrm{mEq}$ \\
Sulfato de magnésio & $8 \mathrm{mEq}$ \\
Excipiente q.s.p. & $40 \mathrm{ml}$ \\
\hline
\end{tabular}

\section{C}

\begin{tabular}{lr}
\hline Bicarbonato de sódio & $8 \mathrm{mEq}$ \\
Excipiente q.s.p. & $40 \mathrm{ml}$ \\
\hline
\end{tabular}

\section{$D$}

Glutamato

$30 \mathrm{mM}$

Aspartato

$30 \mathrm{mM}$

Excipiente q.s.p.

$40 \mathrm{ml}$

\section{TABELA 1 (Continuação)}

Após a mistura a composição da solução "mãe" será:

SOLUÇĀO "MÄE" PARA CARDIOPLEGIA SANGÜÍNEA

\begin{tabular}{lr}
\hline & INDUÇÃO \\
\hline Soro glicosado $5 \%$ & $370 \mathrm{ml}$ \\
Ácido cítrico & $0,132 \mathrm{~g}$ \\
Citrato de sódio & $0,396 \mathrm{~g}$ \\
Dextrose & $0,441 \mathrm{~g}$ \\
Cloreto de potássio & $50 \mathrm{mEq}$ \\
Sulfato de magnésio & $08 \mathrm{mEq}$ \\
Bicarbonato de sódio & $08 \mathrm{mEq}$ \\
Papaverina & $40 \mathrm{mg}$ \\
Glutamato & $30 \mathrm{mM}$ \\
Aspartato & $30 \mathrm{mM}$ \\
Insulina simples & $10 \mathrm{un}$ \\
Volume total & $500 \mathrm{ml}$ \\
\hline
\end{tabular}

nentes" em frascos de $40 \mathrm{ml}$, bastando diluí-los em soro glicosado a $5 \%$ para termos a solução "mãe" de indução pronta para uso, evitando erros de diluição. Essa solução contém $110 \mathrm{mEq}$ de potássio em 1 litro e, uma vez diluída com 4 litros de sangue, que tem aproximadamente 20 $\mathrm{mEq}$ de potássio $(5 \mathrm{mEq} / \mathrm{l})$, totalizará $120 \mathrm{mEq}$ de potássio em 5 litros de mistura, do que resulta uma concentraçāo final de $24 \mathrm{mEq}$ de potássio por litro de cardioplegia final. O mesmo raciocínio vale para todos os componentes.

Da mesma forma que, para a solução de indução, temos também um kit para a solução de manutençāoreperfusão, que facilita sua preparação. Essa solução contém $30 \mathrm{mEq}$ de potássio em 1 litro e, uma vez diluída com 4 litros de sangue, que tem aproximadamente 20 $\mathrm{mEq}$ de potássio $(5 \mathrm{mEq} / \mathrm{l})$, totalizará $50 \mathrm{mEq}$ de potássio em 5 litros, do que resulta uma concentração de 10 $\mathrm{mEq}$ de potássio por litro de solução final. Com relação ao glutamato e ao aspartato, as soluçōes contêm 60

TABELA 2

COMPONENTES DA SOLUÇĀO CARDIOPLÉGICA DE MANUTENÇĀO-REPERFUSĀO NORMOTÉRMICA USADA NO IMC, E SEUS RESPECTIVOS VOLUMES E CONCENTRAÇŌES.

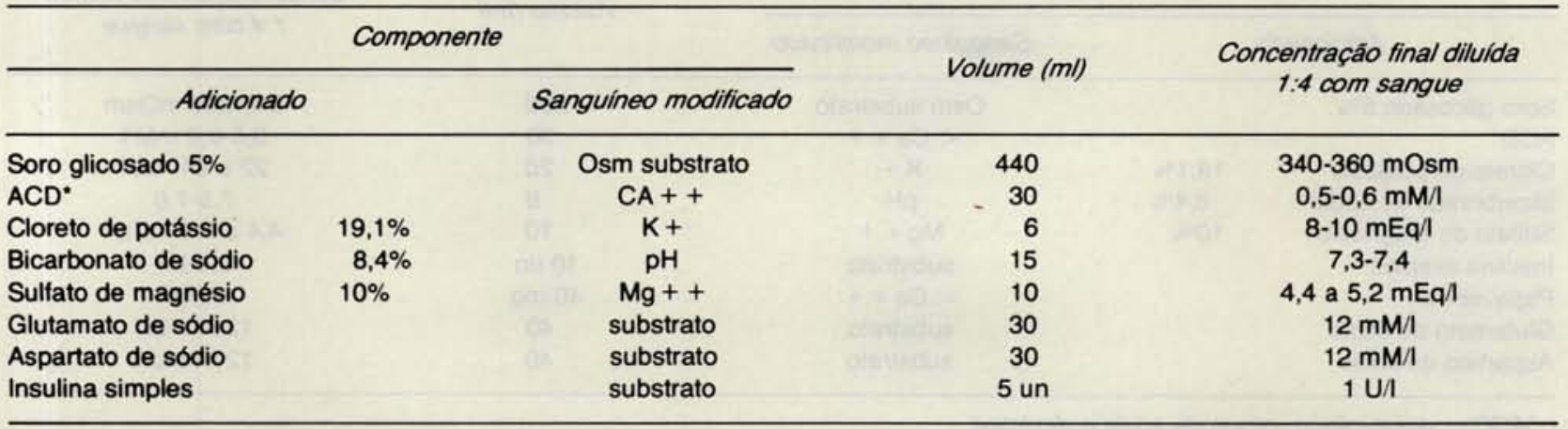

'ACD = ácido citrico, citrato de sódio e dextrose. 
BRAILE, D. M.; ARDITO, R. V.; ZAIANTCHICK, M.; SANTOS, J. L. V.; SOARES, M. J. F. - Cardioplegia sangüínea contínua normotérmica. Rev. Bras. Cir. Cardiovasc., 4(2): 109-138, 1989.

Desenvolvemos um kit"." para cardioplegia de manutençäo e reperfusão, que é constituido por 3 frascos, conforme a especificação seguinte. bastando adiciond-los em $380 \mathrm{ml}$ de soro glicosado para obter a composiçáo adequada: 1 frasco de soluçăo de manutençáo e repertusäo. 2 (ácido citrico, citrato de sódio, dextrose, clorelo de potássio, sulfato de magnésio) (A); 1 frasco de soluçáo de manutencaáo e repertusaáo - 2 (bicarbonato de sódio) (B); 1 frasco de soluçâo (glutamato, aspartato) (C). Acrescentar 5 unidades de insulina simples, a qual náo acompanha o kit, por ser conservada refrigerada. Sequéncia a ser usada, ao adicionar os frascos ao soro glicosado 5\%: $A+B+C$. Caso esta seqüéncia não for obedecida, ocorrerá a precipitaçáo de carbonato de magnésio $\left(\mathrm{MgCO}_{3}\right)$ insolúvel no meio: $\mathrm{Mg}^{+2}+\mathrm{CO}_{3}^{-2} \longrightarrow \mathrm{MgCO}_{3}$

TABELA 2 (Continuação)

\section{$A$}

\section{Ácido cítrico}

$0,132 \mathrm{~g}$

Citrato de sódio

$0,396 \mathrm{~g}$

Dextrose

Cloreto de potássio

Sulfato de magnésio

Excipiente q.s.p.

$0,441 \mathrm{~g}$

$50 \mathrm{mEq}$

$8 \mathrm{mEq}$

$40 \mathrm{ml}$

\section{B}

\begin{tabular}{lr}
\hline Bicaronato de sódio & $15 \mathrm{mEq}$ \\
Excipiente q.s.p. & $40 \mathrm{ml}$ \\
\hline
\end{tabular}

C

\begin{tabular}{lr}
\hline Glutamato & $30 \mathrm{mM}$ \\
Aspartato & $30 \mathrm{mM}$ \\
Excipiente q.s.p. & $40 \mathrm{ml}$ \\
\hline
\end{tabular}
será:

Após a mistura a composição da solução "mãe" SOLUÇÃO "MÄE" PARA CARDIOPLEGIA SANGÜINEA

\section{MANUTENÇĀO E REPERFUSÃO}

\begin{tabular}{lr}
\hline Soro glicosado 5\% & $380 \mathrm{ml}$ \\
Ácido cítrico & $0,132 \mathrm{~g}$ \\
Citrato de sódio & $0,396 \mathrm{~g}$ \\
Dextrose & $0,441 \mathrm{~g}$ \\
Cloreto de potássio & $15 \mathrm{mEq}$ \\
Sulfato de magnésio & $08 \mathrm{mEq}$ \\
Bicarbonato de sódio & $15 \mathrm{mEq}$ \\
Glutamato & $30 \mathrm{mM}$ \\
Aspartato & $30 \mathrm{mM}$ \\
Insulina simples & $05 \mathrm{un}$ \\
Volume total & $500 \mathrm{ml}$ \\
\hline
\end{tabular}

$\mathrm{mMol}$ de glutamato e $60 \mathrm{mMol}$ de aspartato por litro, do que resulta uma solução final com concentração de $12 \mathrm{mMol}$ de cada aminoácido por litro.

\subsection{Filtros}

As soluções que empregamos estāo contidas em frascos de vidro e passam, antes da mistura, por filtros com poros de 0,8 $\mu \mathrm{m}$. As soluções superconcentradas preparadas com potássio, $A C D$, magnésio, aspartato, glutamato, papaverina etc. são previamente filtradas em filtros de nitrocelulose de $0,2 \mu \mathrm{m}$. Temos restriçōes ao uso de frascos plásticos, tanto de polietileno como de PVC, pelo número de partículas, bactérias e substâncias tóxicas (cloro) que possam conter.

\subsection{Trocador de Calor}

Após a mistura dos "componentes" com o sangue, a cardioplegia passa por um trocador de calor de tubos de alumínio anodizados e impermeabilizados com área de troca de $0,7 \mathrm{~m}^{2}$. Este permite uma rápida troca de calor para manutençāo da temperatura adequada do miocárdio (Figura 3). A temperatura do paciente é mantida em torno de $34^{\circ} \mathrm{C}$ nos coronarianos valvulares ou congênitos.

\subsection{Circuito de Cardioplegia}

Como se pode observar na Figura 2, o circuito de cardioplegia é constituído por dois frascos de solução "mãe", o primeiro com solução de indução e o segundo com soluçāo de manutenção-reperfusão, que, ligados por $Y$, vão a um filtro de $0,8 \mu \mathrm{m}$, seguindo para a bomba de roletes com o tubo de PVC de 1/8" de diâmetro, que termina em outro $\mathrm{Y}$. O depósito, ou a linha arterial, liga-se à bomba de roletes com o tubo de PVC de 1/4" de diâmetro, que vai terminar no mesmo $Y$ que a solução

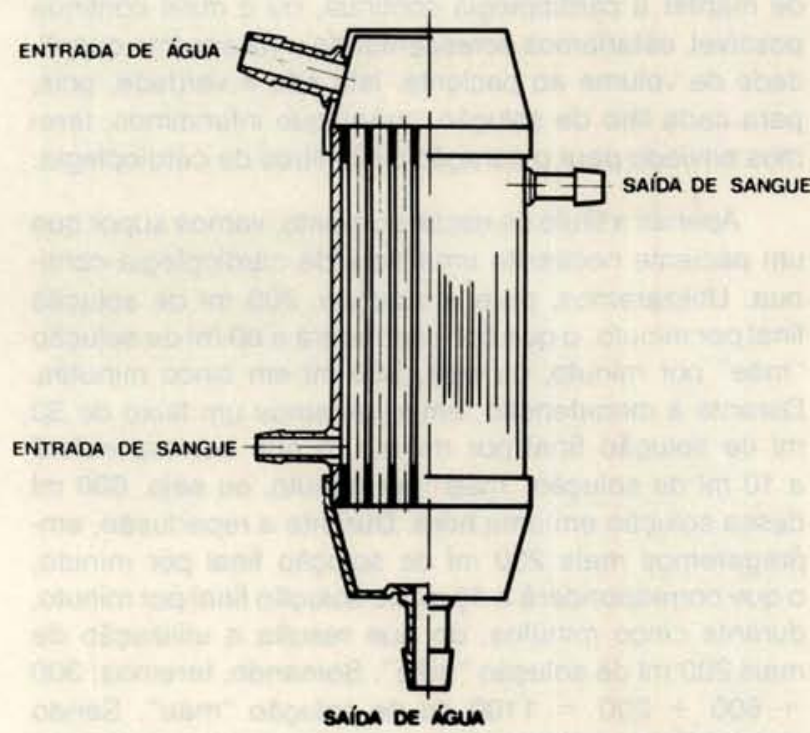

Fig. 3 - Representação esquemática do trocador de calor modelo TC 80.600 IMC Biomédica usado em cardioplegia: volume de "pri$\mathrm{me}^{\prime \prime}=83 \mathrm{ml}$, superficie de troca $-700 \mathrm{~cm}^{2}$. 
BRAILE, D. M.; ARDITO, R. V.; ZAIANTCHICK, M.; SANTOS, J. L. V.; SOARES, M. J. F. - Cardioplegia sangüínea contínua normotérmica. Rev. Bras. Cir. Cardiovasc., 4(2): 109-138, 1989.

"mãe". O sangue e a solução "mãe" juntam-se nesse $Y$ e passam pelo trocador de calor, seguindo para o campo operatório por um tubo de PVC de 1/4". Através de pinçamento dos tubos que saem dos frascos, é possível selecionar qual da soluçōes desejamos injetar, sem que entre ar no circuito. A precisão com que a bomba de cardioplegia faz a mistura 1:4 é fundamental para que a cardioplegia funcione adequadamente. Se a "continência" dos roletes nāo for perfeita, a diluição pode não ser correta, com conseqüências desastrosas para o paciente. Em geral, quando o coraçāo nāo pára durante a cardioplegia, a causa é uma mistura inadequada de soluçāo "māe" com sangue (muito sangue e pouca solução "māe").

\subsection{Fluxos}

Temo-nos guiado muito mais pela pressão da raiz da aorta que pelo fluxo propriamente dito. De forma geral, durante a indução, o fluxo fica em torno de $300 \mathrm{ml} / \mathrm{minuto}$, de $50-150 \mathrm{ml} /$ minuto durante a manutenção e cerca de 200-300 $\mathrm{ml} /$ minuto durante a reperfusão.

Voltamos a insistir em que consideramos o tempo mais importante que o volume e, sempre, quando fazemos uma reinfusão, após uma interrupção da cardioplegia, procuramos mantê-la pelo menos por dois minutos. Lembramos que o coração parado só consome $10 \%$ de energia (para manutenção da viabilidade celular) e, por isto, o fluxo da cardioplegia, em geral, não necessita ser maior que $10 \%$ do fluxo coronariano original.

\subsection{Volumes}

Pode-se ter a impressão de que, com o conceito de manter a cardioplegia contínua, ou o mais contínua possível, estaríamos acrescentando uma enorme quantidade de volume ao paciente. Isto não é verdade, pois, para cada litro de solução "mãe" que infundimos, teremos enviado para o coração cinco litros de cardioplegia.

Apenas a título de esclarecimento, vamos supor que um paciente necessite uma hora de cardioplegia continua. Utilizaremos, para a indução, $300 \mathrm{ml}$ de solução final por minuto, o que corresponderá a $60 \mathrm{ml}$ de solução "mãe" por minuto, ou seja, $\mathbf{3 0 0} \mathrm{ml}$ em cinco minutos. Durante a manutenção, empregaremos um fluxo de 50 $\mathrm{ml}$ de soluçāo final por minuto, o que corresponderá a $10 \mathrm{ml}$ de solução "mãe" por minuto, ou seja, $600 \mathrm{ml}$ dessa solução em uma hora. Durante a reperfusão, empregaremos mais $200 \mathrm{ml}$ de solução final por minuto, o que corresponderá a $40 \mathrm{ml}$ de solução final por minuto, durante cinco minutos, do que resulta a utilização de mais $200 \mathrm{ml}$ de solução "mãe". Somando, teremos: $\mathbf{3 0 0}$ $+600+200=1100 \mathrm{ml}$ de solução "mãe". Sendo cinco minutos para indução, uma hora de manutenção e cinco minutos para reperfusão. Sempre é bom lembrar que, em cirurgias muito longas, podemos lançar mão da ultrafiltração, o que torna o uso da cardioplegia ilimitado. Como regra geral, procuramos manter o hematócrito do paciente acima de $25 \%$, o que se tem mostrado muito conveniente para melhor transporte de $\mathrm{O}_{2}$, além de evitar diluiçāo excessiva, que pode levar a problemas no pósoperatório (pulmão úmido, edema tecidual, etc). A solução de manutenção-reperfusāo tem uma concentraçāo final de potássio de apenas $10 \mathrm{mEq} / \mathrm{l}$, o que, dificilmente, leva a hiperpotassemia em pacientes adultos, ou com peso superior a $30 \mathrm{~kg}$. Lembramos que um paciente de $60 \mathrm{~kg}$ tem cerca de $4000 \mathrm{mEq}$ de potássio no organismo. Durante uma hora de cardioplegia, introduzimos na circulação cerca de $200 \mathrm{mEq}$ de potássio, o que é uma pequena quantidade comparada aos $4000 \mathrm{mEq}$ existentes.

\subsection{Baixo Peso}

Quando lidamos com crianças de baixo peso, procuramos limitar os volumes de soluções "mãe" ao seguinte: solução "mãe" de indução $3,0 \mathrm{ml} / \mathrm{kg}$ e solução "mãe" de manutenção-reperfusāo 10 a $20 \mathrm{ml} / \mathrm{kg}$. Assim, para uma criança de $10 \mathrm{~kg}$, teríamos uma infusāo de apenas $140 \mathrm{ml}$ de soluão "mãe" e teríamos fornecido, à mesma, $700 \mathrm{ml}$ de cardioplegia.

\subsection{Indução Quente}

Nos pacientes graves com isquemia prévia, instabilidade hemodinâmica, hipertrofia e dilatação acentuada, temos empregado induçāo cardioplégica quente por um período maior, seguida de cardioplegia de manutenção. $A$ indução quente teria, como já vimos, a finalidade de melhorar as reservas do coração debilitado antes da isquemia. Temos empregado indução quente em todos os casos (se é bom para os coraçōes ruins, deve ser ótimo para aqueles em melhores condiçōes). Como já descrevemos, fazemos a indução (com a solução de indução) apenas até a parada completa dos batimentos e completamos o tempo de indução (5 minutos) com o uso da soluçāo de manutenção-reperfusāo. Lembramos que parte do bloqueio do cálcio é feito nesta solução pelo uso da papaverina, não sendo, assim, necessárias altas doses de ACD.

\subsection{Técnica Cirúrgica para Casos Especiais}

Descrevemos, até aqui, em linhas gerais, o emprego da cardioplegia sangüínea modificada, normotérmica e contínua. Para seu emprego exigem-se táticas diferentes, de acordo com a operação a ser realizada:

1) Coronarianos - entramos em circulação extracorpórea tão logo os tubos estejam instalados. Após avaliação das pontes a serem realizadas, medimos 0 comprimento das veias, desde o ponto da anastomose 
BRAILE, D. M.; ARDITO, R. V.; ZAIANTCHICK, M.; SANTOS, J. L. V.; SOARES, M. J. F. - Cardioplegia sangüínea contínua normotérmica. Rev. Bras. Cir. Cardiovasc., 4(2): 109-138, 1989.

distal até a raiz da aorta. Fazemos as anastomoses proximais usando pinçamento lateral da aorta com o coração batendo vazio (PAE abaixo de $4 \mathrm{mmHg}$ e sem ejeção pela aorta). Durante esse período, parte dos déficits de energia podem ser restaurados, pois o coração bate sem trabalho efetivo, com baixo consumo. Terminadas as anastomoses proximais, faz-se a indução cardioplégica após pinçamento total da aorta, realizando a primeira anastomose para a área de maior risco. Ao término de cada anastomose distal, reinfundimos cardioplegia de manutenção por 2 minutos. As interrupçōes do fluxo cardioplégico são curtas ( 4 a 8 minutos) e limitam-se aos tempos das anastomoses distais (se uma anastomose se prolonga, reinfundimos cardioplegia). Antes da última anastomose, iniciamos o aquecimento, sendo a última infusão já de reperfusão quente. Esta dura 4-5 minutos, ao fim dos quais retiramos a pinça da aorta. No caso do uso da artéria mamária, deixamos a mesma clampeada até a liberação da pinça da aorta.

2) Aórticos - inicialmente, procuramos fazer sempre uma indução pela raiz da aorta. Se o grau de insuficiência não permite, abrimos rapidamente a aorta e infundimos a cardioplegia diretamente nos óstios coronarianos com fluxo de $250 \mathrm{ml} /$ minuto para a coronária esquerda, e $150 \mathrm{ml} /$ minuto para a coronária direita, dependendo de sua importância. Nesses casos, a monitorização da temperatura é de grande auxilio e orientação. Dependendo da gravidade do caso, fazemos retroplegia com confecção de uma bolsa de Prolene 4-0 no seio coronariano, e a introdução de uma sonda especialmente desenvolvida, mantendo-a fixa no local com a bolsa. Novas cânulas com balão auto-inflável para retroplegia foram desenvolvidas por Buckberg. Elas permitem a retroplegia com o uso de cânulas venosas de duplo estágio, simplesmente introduzindo-as através de uma bolsa no átrio direito e atingindo o seio coronariano às cegas. Essa cânula dispõe de uma dupla luz: uma delas abrindo-se à frente dos orifícios de infusão, permitindo a medida de pressão do seio coronariano. É muito útil, também, medir a pressão da linha de infusão da cardioplegia, que nos orienta com respeito a obstruções do sistema ou a desinsuflação do balonete. A experiência com esse tipo de cânula tem sido excelente e, sem dúvida, foi mais uma inestimável contribuição desse grande pesquisador, Dr. Gerald Buckberg. Para a cardioplegia retrógrada, faz-se a infusão da cardioplegia de manutençãoreperfusão com fluxo de mais ou menos 80 a $120 \mathrm{ml}$ por minuto (da solução final). Podemos observar, no início, saída de sangue muito saturado e, depois, menos insaturado pelos óstios coronarianos. Mesmo com essa proteção, nos casos de hipertrofia ou dilatação com déficit contrátil acentuado, vale a pena fazer uma "dose" de 2 minutos de cardioplegia anterógrada a cada 10 ou 15 minutos. Atenção especial tem que ser dada à proteção do ventrículo direito, durante a retroperfusão, como já estudamos. A técnica acima descrita tem aplicação muito conveniente para os casos de dissecção aguda da aorta, nos quais o tempo de pinçamento é longo e a canulação dos óstios coronarianos, difícil.
3) Infarto Agudo - à cardioplegia anterógrada com indução quente temos acrescentado retroplegia, para que os benefícios da solução cardioplégica possam atingir, por via venosa, a área infartada, onde dificilmente chegaria por via anterógrada. A técnica é a mesma descrita para os aórticos, devendo-se prover aspiração da raiz da aorta para retirada do efluente dos óstios coronarianos.

4) Reoperação de Coronarianos - A retroplegia tem-se mostrado um valioso método durante essas reoperaçōes, permitindo menor risco pela manipulação dos enxertos e lavagem da árvore coronariana por via retrógrada. A associação da cardioplegia anterógrada e retrógrada deve, portanto, ser considerada para esses casos.

\subsection{Hipotermia de Superfície no Coração}

Não utilizamos.

\subsection{Uso de Removedores (Scavengers)}

Temos empregado, de rotina, alopurinol $300 \mathrm{mg} 3$ vezes ao dia, vitamina $E 250$ unidades 3 vezes ao dia, durante os 3 dias que antecedem a cirurgia (exceto casos de urgência). No momento da operação, introduzimos, pela sonda gástrica, $300 \mathrm{mg}$ de alopurinol e 750 unidades de vitamina $\mathrm{E}$.

No circuito extracorpóreo, utilizamos manitol, glicose, insulina, corticosteróides e vitamina C, que apresentam propriedades protetoras em relação à formação dos radicais livres e à manutenção da integridade da membrana celular e do endotélio vascular.

\section{RESULTADOS}

Não é fácil avaliar os resultados de uma técnica que teve seu emprego progressivamente desenvolvido e melhorado. Não contamos, também, com um grupo controle, pois não nos sentimos autorizados a fazê-lo, uma vez que a segurança oferecida pela técnica é fundamental para a boa evolução dos mesmos.

De julho de 1987 a junho de 1990, operamos 2195 pacientes com circulação extracorpórea, compreendendo: revascularização miocárdica em infarto agudo em choque; valvulares com função deteriorada, endocardite ou mesmo em edema agudo de pulmão; hipertróficos, cianóticos, etc.

Nesse período, não recusamos nenhum paciente para a cirurgia.

A mortalidade global, hospitalar (30 dias) e a imediata (cirurgia, UTI) foram divididas em 3 anos (Tabela 3) e representam um atestado de qualidade dos métodos de proteção miocárdica empregados. Principalmente se 
BRAILE, D. M.; ARDITO, R. V.; ZAIANTCHICK, M.; SANTOS, J. L. V.; SOARES, M. J. F. - Cardioplegia sangüínea contínua normotérmica. Rev. Bras. Cir. Cardiovasc., 4(2): 109-138, 1989.

considerarmos a mortalidade da cirurgia e da UTI, que ficaram abaixo de $1 \%$ e que, raramente, decorreram de falência de bomba. Reiteramos, contudo, mais uma vez, o fato de que nos falta um "marcador" eficaz que pudesse diferenciar de forma inequívoca a validade de um determinado método de proteção miocárdica.

Estudamos por bio-impedância 10 pacientes coronarianos no pré e pós-operatório. Foi demonstrado que nenhum deles apresentou qualquer sinal de depressão da função cardíaca nas medidas em que foram feitas, logo após chegada à UTI, e em períodos de 3, 6 e 12 horas de pós-operatório (Tabela 4). Nenhum destes pacientes recebeu drogas inotrópicas e nenhum deles faleceu.

Para análise estatística, foram medidos o débito cardíaco (DC), a freqüência cardiaca (FC) e o volume de ejeção (VE). Para essas grandezas, foram feitas duas medidas no pré-operatório e quatro no pós-operatório, cujos resultados sāo apresentados na Tabela 4. Foram calculados a média e o desvio padrão para cada uma das grandezas (DC, FC, VE) no pré e pós-operatório, sendo que para o pré-operatório fez-se uma média entre os dois valores tabelados (0-30 minutos). Este valor médio foi, então, comparado com os valores de $0,3,6$ e

TABELA 3

MORTALIDADE GLOBAL NO PERIODO DE JULHO DE 1987 A JUNHO DE 1990 (DIVIDIDA EM 3 ANOS). 2.195 PACIENTES.

\begin{tabular}{lcccc}
\hline PERIODO & $\begin{array}{c}1: \text { ANO } \\
\text { MORTALIDADE GLOBAL }\end{array}$ & $\begin{array}{c}2: \text { ANO } \\
(755)\end{array}$ & $\begin{array}{c}3: \text { ANO } \\
(787)\end{array}$ \\
\hline $\begin{array}{l}\text { Mortalidade } \\
\begin{array}{l}\text { Cirurgia } \\
\text { UTI }\end{array}\end{array}$ & $0,97 \%$ & $0,89 \%$ & $0,35 \%$ \\
Mortalidade Hospitalar & $3,12 \%$ & $4,36 \%$ & $3,25 \%$ \\
\hline
\end{tabular}

12 horas do pós-operatório. O teste estatístico usado foi o T de Student para dados pareados, sendo que a hipótese nula era de igualdade entre as médias e a hipótese complementar de diferença entre elas. Os resultados deste teste de hipótese estão registrados na Tabela 5 , mostrando não haver diferença significativa para DC e VE no pré e pós-operatório, mas havendo diferença para FC. Se, no teste complementar, a média do pós-operatório fosse maior que a do pré, ainda assim haveria significância estatística. Para o cálculo do índice cardíaco (IC) no pré e pós-operatório, foram utilizados os índices de débito cardíaco (Tabela 4) e de superfície corpórea (Tabela 6). No teste de hipótese aplicado foi usada, também, a estatística $T$ de Student, cuja hipótese nula era de igualdade entre as médias e a complementar de diferença entre elas. Os resultados mostraram que a cirurgia não provocou nenhum dano ao paciente coronariano sob cardioplegia sangüínea, quando analisamos os dados de índice cardíaco no pré e pós-operatório (Tabela 7).

\section{COMENTÁRIOS}

Atualmente, a proteção miocárdica atingiu a maior parte das profecias que foram feitas ao longo do tempo e reiteradas há cinco anos atrás.

A cardioplegia tem sido considerada mandatória para operaçōes seguras sobre o coração, principalmente agora que os pacientes de alto risco têm aumentado, pela ampliação da indicação cirúrgica em neonatos, idosos e isquêmicos.

Orupo dos isquêmicos tem sido de particular interesse, podendo eles ser operados no período pré-isquêmico, durante a isquemia aguda, ou mesmo após a reperfusão clínica dessas áreas.

A medida em que operamos mais pacientes nas fases de isquemia e reperfusão, mais enfática se torna

TABELA \&

DADOS DE DÉBITO CARDIACO, FREQÜEANCIA CARDIACA E VOLUME DE EJEÇÃO EM PACIENTES CORONARIANOS NOS PERIODOS PRÉ E POSS-OPERATORIO.

\begin{tabular}{|c|c|c|c|c|c|c|c|c|c|c|c|c|c|c|c|c|c|c|}
\hline \multicolumn{7}{|c|}{ PACIENTE DÉBITO CARDIACO (1MIN) } & \multicolumn{6}{|c|}{ FREQÜENCIA CARDIACA (MIN') } & \multicolumn{6}{|c|}{ VOLUME DE EJEÇÃO (ML) } \\
\hline \multicolumn{3}{|c|}{ PRÉ (MIN) } & \multicolumn{4}{|c|}{$P O S(H)$} & \multicolumn{2}{|c|}{ PRÉ (MIN) } & \multicolumn{4}{|c|}{$P O S(H)$} & \multicolumn{2}{|c|}{ PRÉ (MIN) } & \multicolumn{4}{|c|}{$P O S(H)$} \\
\hline & 0 & 30 & 0 & 3 & 6 & 12 & $\overline{0}$ & 30 & $\overline{0}$ & 3 & 6 & 12 & $\overline{0}$ & 30 & 0 & 3 & 6 & 12 \\
\hline 1 & 5,1 & 5,4 & & 6,3 & 5,1 & 5,1 & 99,0 & 103,4 & 110,3 & 107.7 & 95,0 & 95,5 & 51,6 & 53,0 & 62,0 & 58,7 & 54,0 & 53,5 \\
\hline 2 & 5,8 & 6,4 & 6,6 & 6,2 & 6,8 & 6,6 & 69,8 & 67,6 & 105,7 & 111,7 & 110,3 & 97,7 & 83,0 & 94,4 & 62,0 & 59,0 & 61,7 & 60,3 \\
\hline 3 & 4,5 & 4,2 & 6,5 & 6,1 & 4,5 & 5,1 & 78,6 & 74,2 & 107,0 & 94,7 & 83,0 & 111,0 & 57,4 & 56,4 & 61,0 & 64,3 & 55,5 & 45,5 \\
\hline 4 & 3,6 & 3,8 & 3,9 & 5,5 & 5,4 & 4,7 & 72,2 & 73,0 & 66,3 & 77,3 & 90,0 & 99,7 & 51,0 & 52,6 & 59,7 & 70,7 & 60,7 & 47,7 \\
\hline 5 & 4,4 & 4,6 & 4,0 & 3,8 & 4,5 & 4,4 & 65,8 & 75,4 & 87,3 & 94,7 & 82,3 & 83,0 & 66,8 & 61,2 & 46,0 & 40,7 & 55,3 & 55,3 \\
\hline 6 & 6,2 & 6,0 & 6,3 & 6.6 & 6,2 & 6,0 & 76,0 & 73,8 & 122,5 & 121,0 & 92,0 & 92,0 & 81,6 & 82,4 & 52,0 & 54,5 & 66,3 & 64,0 \\
\hline 7 & 5,2 & 5,5 & 5,5 & 4,8 & 6,4 & 5,4 & 92,6 & 88,4 & 97,5 & 84,0 & 95,3 & 92,3 & 55,4 & 62,0 & 56,5 & 57,5 & 68,3 & 59,0 \\
\hline 8 & 4,3 & 4,2 & 4,2 & 3,9 & 4,4 & 4,5 & 78,2 & 79,0 & 93,7 & 98,7 & 100,4 & 101,0 & 55,4 & 53,2 & 44,7 & 40,0 & 44,3 & 44,7 \\
\hline 9 & 3,6 & 3,2 & 3,5 & 3,3 & 3,0 & 3,4 & 97,8 & 90,6 & 98,0 & 98,7 & 96,0 & 95,3 & 36,8 & 36,0 & 35,0 & 33,0 & 31,7 & 35,0 \\
\hline 10 & 4,7 & 4,8 & 3,7 & 4,4 & 3,5 & 5,6 & 71,0 & 71,4 & 75,3 & 80,0 & 80,0 & 78,0 & 66,4 & 67,6 & 48,7 & 54,7 & 43,0 & 73,0 \\
\hline
\end{tabular}


BRAILE, D. M.; ARDITO, R. V.; ZAIANTCHICK, M.; SANTOS, J. L. V.; SOARES, M. J. F. - Cardioplegia sangüinea contínua normotérmica. Rev. Bras. Cir. Cardiovasc., 4(2): 109-138, 1989.

TABELA 5

ESTUDO ESTATISTICO EM COMPARAÇÃO ENTRE PRÉ E POS-OPERATORIO PARA DÉBITO CARDIACO, FREQÜENCIA CARDIACA E VOLUME DE EJEÇAOO EM PACIENTES CORONARIANOS.

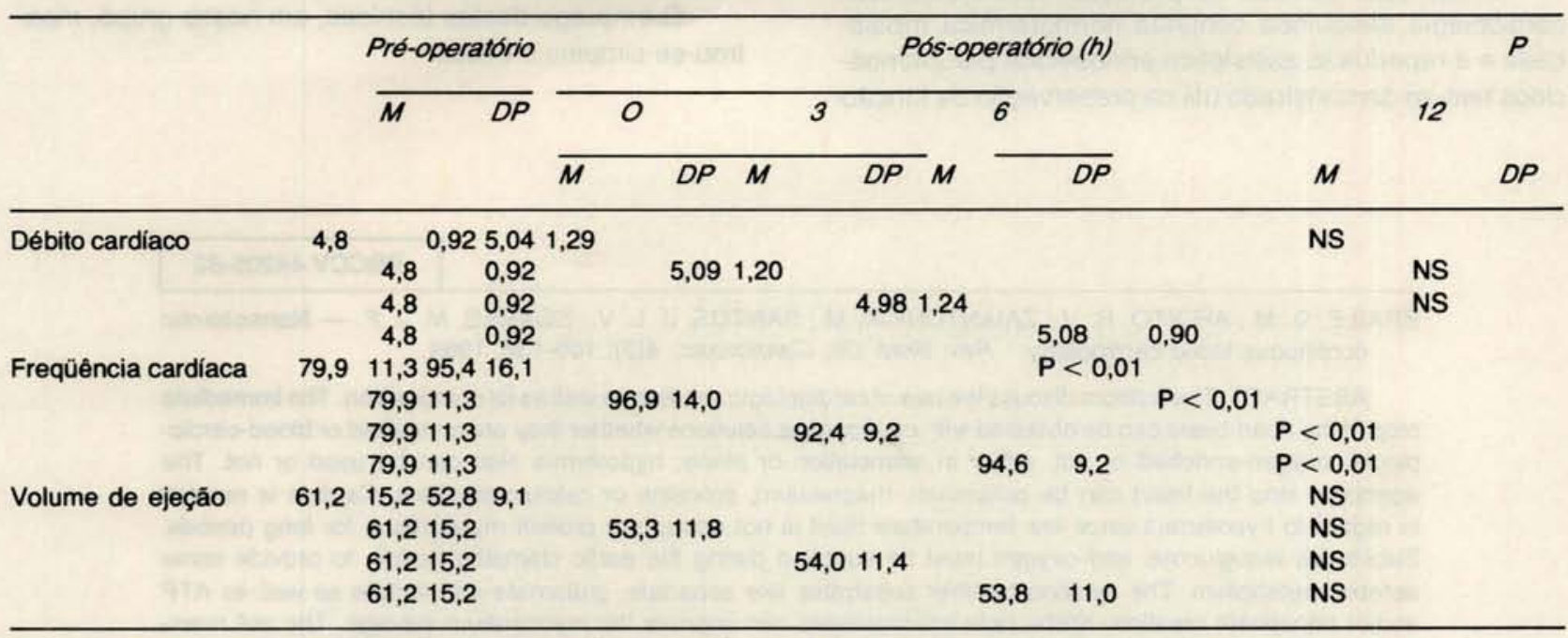

$M=$ média; $D P=$ desvio padrão; $P$ = nível significância; $N S$ = não significativo.

TABELA 6

INDICE DE SUPERFICIE CORPÓREA DOS PACIENTES CORONARIANOS ESTUDADOS.

\begin{tabular}{cc}
\hline PACIENTE & $\begin{array}{c}\text { SUPERFICIE CORPOREA } \\
\left(\mathrm{m}^{2}\right)\end{array}$ \\
\hline 1 & 1,86 \\
2 & 2,01 \\
3 & 1,96 \\
4 & 1,78 \\
5 & 1,86 \\
6 & 1,86 \\
7 & 1,86 \\
8 & 1,86 \\
9 & 1,39 \\
10 & 1,75 \\
\hline
\end{tabular}

a necessidade de uma cardioplegia de ressuscitação, contrapondo-se a uma simples solução para inibir o metabolismo.
É interessante notar que uma geração de cirurgiōes está emergindo sem ter tido contato com a era pré cardioplegia e a aplicação prática desta tem dependido muito mais de técnica do que da química que ela envolve. Assim, vale a pena ressaltar a necessidade de o cirurgião cardiaco voltar às bases fundamentais da fisiologia e da bioquímica cardíaca, para estar apto a absorver novos conceitos que surgem e evoluem no dia-a-dia, não se conformando em, simplesmente, repetir técnicas que tenham sido desenvolvidas por outros, sem entendê-las completamente.

É mister das novas geraçōes contribuir para o efetivo desenvolvimento deste campo, buscando, não só preservar a energia durante o pinçamento aórtico, mas, ainda, melhorar as condições do miocárdio sob risco, revitalizando-o e permitindo que retorne, com todo vigor, à sua função contrátil, para a manutenção da circulação e da vida.

TABELA 7

INDICE DE SUPERFICIE CORPÓREA DOS PACIENTES CORONARIANOS ESTUDADOS.

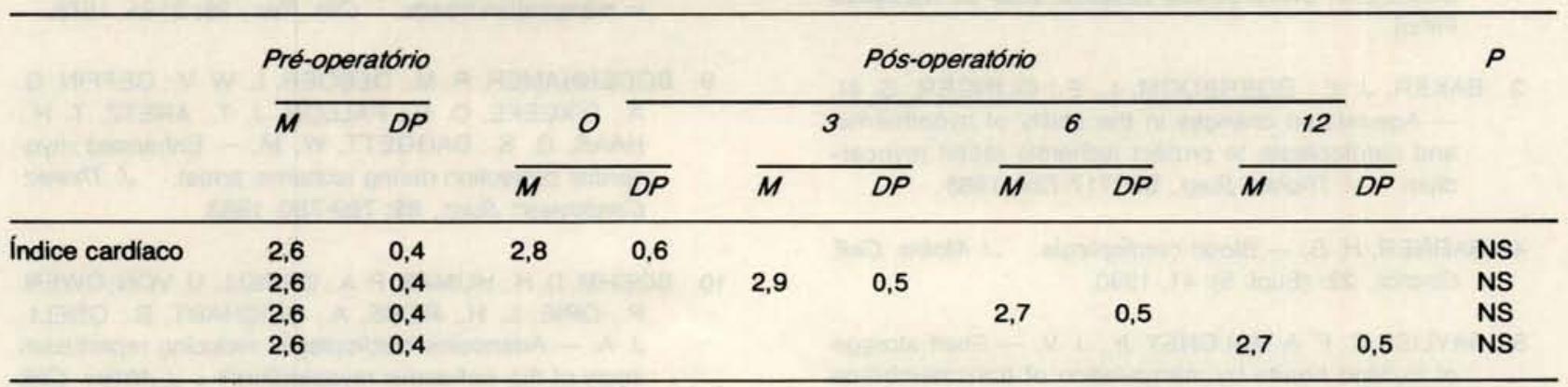

$M=$ média; $D P=$ desvio padrão; $P$ = nível significância; $N S$ = não significativo. 
BRAILE, D. M.; ARDITO, R. V.; ZAIANTCHICK, M.; SANTOS, J. L. V.; SOARES, M. J. F. - Cardioplegia sangüínea contínua normotérmica. Rev. Bras. Cir. Cardiovasc., 4(2): 109-138, 1989.

\section{CONCLUSÃO}

O uso das técnicas de proteção miocárdica com cardioplegia sangüínea contínua normotérmica modificada e a reperfusão assistólica enriquecida por aminoácidos tem-se demonstrado útil na preservação da função miocárdica e na reversão dos danos isquêmicos, como demonstrado por Buckberg.

O emprego destas técnicas, em nosso grupo, mostrou-se simples e eficaz.

RBCCV 44205-83

BRAILE, D. M.; ARDITO, R. V.; ZAIANTCHICK, M.; SANTOS, J. L. V.; SOARES, M. J. F. - Normotermic continuous blood cardioplegy. Rev. Bras. Cir. Cardiovasc., 4(2): 109-138, 1989.

ABSTRACT: The authors discuss the use of cardioplegic solution as well as its composition. The immediate stop of the heart beats can be obtained with cardioplegic solutions whether they are crystalloid or blood-cardioplegia, oxygen-enriched or not, either in association or alone; hypotermia also can be used or not. The agents to stop the heart can be potassium, magnesium, procaine or calcium blockers. Caution is needed in regard to hypotermia since low temperature itself is not enough to protect myocardium for long periods. Substrates like glucose and oxygen must be supplied during the aortic clamping period, to provide some aerobic metabolism. The addition of other substrates like aspartate, glutamate and lactate as well as ATP and/or phosphate creatine, Krebs cicle intermediates can improve the myocardium salvage. The cell membrane, with all its structural, selective and secretory functions, is the most sensible region to ischemic injure. The retrograde cardioplegy allows a better difusion of the solutions. We believe that it should be part of any cardiac surgery, although we must be aware of its limitations. Perfusion is the most important step of the myocardium salvage when the delivery of free radicals occurs, so the use of scavengers can improve the results of reperfusion. The normotermic blood oxygenated cardioplegy in enriched with substrates was used initially in extremely severe cases of muscle dysfunction, in severe myocardium ischemia or for lack of adequate protection during ischemia and/or reperfusion, and now has been extended to all cases. It is advisable to have the heart chambers always drained, avoiding any increase of tension on the walls which would lead to a higher oxygen consumption. The authors describe the technique and the solution for cardioplegy used in the Cardiac Service of IMC and the results achieved with its use. They conclude that the use of blood modified normotermic cardioplegy aminoacid-enriched and asystolic reperfusion are satisfactory in myocardium salvage and for reverting the ischemic injures.

DESCRIPTORS: myocardial protection, cardioplegia; calcium blockers; free radicals.

\section{REFERÊNCIAS BIBLIOGRÁFICAS}

1 ADDETIA, A. M. G.; O'REILLY, B. F.; WALSH, G. W.; REID, P. - Prolonged asystole during intraoperative myocardial reperfusion: an experimental study. Ann. Thorac. Surg., 45: 482-488, 1988.

2 ANDRADE, R. R. - Infusão intermitente de solução cardioplégica hipotérmica pelo seio coronário na isquemia miocárdica global: estudo funcionale ultraestrutural em coraçōes isolados de cães. Botucatu, 1983. [Tese. Doutorado. Universidade Estadual Júlio de Mesquita Filho].

3 BAKER, J. E.; BOERBOOM, L. E.; OLINGER, G. N. - Age-related changes in the ability of hypothermia and cardioplegia to protect ischemic rabbit myocardium. J. Thorac. Surg., 96: 717-724, 1988.

4 BARNER, H. B. - Blood cardioplegia. J. Molec. Cell. Cardiol., 22: (Supl. 5): 41, 1990.

5 BAYLISS C. F. \& MALONEY Jr., J. V. - Shelf storage of excised hearts by manipulation of transmembrane ionic gradients. Surg. Forum, 21: 194-195, 1970.
6 BECK, C. S. - Revascularization of the heart. Ann. Surg., 128: 854-870, 1948.

7 BECKER, H.; VINTEN-JOHANSEN, J.; BUCKBERG, G. D.; ROBERTSON, J. M.; LEAF, J. D.; LAZAR, H. L.; MANGANARO, A. J. - Myocardial damage caused by keeping $\mathrm{pH} 7,40$ during systemic deep hipothermia. J. Thorac. Cardiovasc. Surg., 82: 810-820, 1981.

8 BERKOWITZ, S.; PERILLE, T.; LEACH, M. - Anaerobic amino acid metabolism as a potential energy source in mammalian hearts. Clin. Res., 26: 219A, 1978.

9 BODENHAMER, R. M.; DEBOER, L. W. V.; GEFFIN, G. A.; O'KEEFE, D. D.; FALLON, J. T.; ARETZ, T. H.; HAAS, G. S.; DAGGETT, W. M. - Enhanced myocardial protection during ischemic arrest. $J$. Thorac. Cardiovasc. Surg., 85: 769-780, 1983.

10 BOEHM, D. H.; HUMAN, P. A.; OPPELL, U. VON; OWEN, P.; OPIE, L. H.; ROSE, A.; REICHART, B.; ODELL, J. A. - Adenosine cardioplegia: reducing reperfusion injury of the ischaemic myocardium? J. Molec. Cell. Cardiol., 22: (Supl. 5): S5, 1990. 
BRAILE, D. M.; ARDITO, R. V.; ZAIANTCHICK, M.; SANTOS, J. L. V.; SOARES, M. J. F. - Cardioplegia sangüinea contínua normotérmica. Rev. Bras. Cir. Cardiovasc., 4(2): 109-138, 1989.

11 BOGGS, B. R.; TORCHIANA, D. F.; GEFFIN, G. A.; TITUS, J. S.; REDONNETT, B. E.; O'KEEFE, D. D.; NEWELL, J. B.; DAGGETT, W. M. - Optimal myocardial preservation with an acalcemic crystalloid cardioplegic solution. J. Thorac. Cardiovasc. Surg., 93: 838-846, 1987.

12 BOLLING, S. F.; FLAHERTY, J. T.; BULKLEY, B. H.; GOTT, V. L.; GARDNER, T. J. - Improved myocardial preservation during global ischemia by continuous retrograde coronary sinus perfusion. J. Thorac. Cardiovasc. Surg., 86: 659-666, 1983.

13 BONCHEK, L. J. \& BURLINGAME, M. W. - Coronary artery bypass without cardioplegia. J. Thorac. Cardiovasc. Surg., 93: 261-267, 1987.

14 BRAILE, D. M.; BILAQUI, A.; ANACLETO, J. C.; ARAÚJO, J. D.; BELLINI, A. J.; GARZON, S. A. C.; GRECO, O. T.; ARDITO, R. V.; AYOUB, J. C. A.; BAUCIA, J. A.; WICHTENDAHL, R. F. T.; KURODA, G. Y.; LORGA, A. M. - Proteçāo miocárdica por cardioplegia. Arq. Bras. Cardiol., 33: (Supl. 1): 199-210, 1979.

15 BRAIMBRIDGE, M. V.; CHAYEN, J.; BITENSKY, L.; HEARSE, D. J.; JYNGE, P.; CANKOVIÉDARRACOTT, S. - Cold cardioplegia or continuous coronary perfusion: report on preliminary clinical experience as assessed cytochemically. J. Thorac. Cardiovasc. Surg., 74: 900-906, 1977.

16 BRAZIER, J.; HOTTENROTT, C.; BUCKBERG, G. Noncoronary collateral myocardial blood flow. Ann. Thorac. Surg., 19: 426-435, 1975.

17 BRETSCHNEIDER, J. H.; HUBGER, G.; KNOLL, D.; LOHR, B.; NORDBECK, H.; SPIECKERMANN, P. G. - Myocardial resistance and tolerance to ischemia: physiological and biochemical basis. J. Cardiovasc. Surg., 16: 241-260, 1975.

18 BUCKBERG, G. D. - Antegrade cardioplegia, retrograde cardioplegia, or both? Ann. Thorac. Surg., 45: 589-590, 1988.

19 BUCKBERG, G. D. - Antegrade/retrograde blood cardioplegia to ensure cardioplegic distribution: operative techniques and objectives. J. Cardiac. Surg., 4: 216-238, 1988.

20 BUCKBERG, G. D. - A proposed solution to the cardioplegic controversy. J. Thorac. Cardiovasc. Surg., 77: 803-817, 1979.

21 BUCKBERG, G. D. - Strategies and logic for cardioplegic delivery to prevent, avoid, and reverse ischemic and reperfusion damage. J. Thorac. Cardiovasc. Surg., 93: 127-139, 1987.

22 BUCKBERG, G. D.; BRAZIER, J. R.; NELSON, R. L.; GOLDSTEIN, S. M.; MCCONNELL, D. H.; COOPER, N. - Studies of the effects of hypothermia on regional myocardial blood flow and metabolism during cardiopulmonary bypass: I. The adequately perfused beating, fibrillating, and arrested heart. J. Thorac. Cardiovasc. Surg., 73: 87-94, 1977.
23 CATINELLA, F. P.; CUNNHINGHAM Jr, J. N.; SPENCER, F. C. - Myocardial protection during prolonged aortic cross-clamping. J. Thorac. Cardiovasc. Surg., 88: 411-413, 1984.

24 CHAMBERS, D. J.; BRAIMBRIDGE, M. V.; HEARSE, D. J. - Free radicals and cardioplegia: allopurinol and oxypurinol reduce myocardial injury following ischemic heart. Ann. Thorac. Surg., 44: 291-297, 1987.

25 CHITWOOD, W. R.; SINK, J. D.; HILL, R. C.; WECHSLER, A. S.; SABISTON Jr, D. C. - The effects of hypothermia on myocardial oxygen consumption and transmural coronary blood flow in the potassium-arrested heart. Ann. Thorac. Surg., 190: 106-116, 1979.

26 CHIU, R. C. J.; BLUNDELL, P. E.; SCOTT, H. J.; CAIN, S. - The importance of monitoring intramyocardial temperature during hypothermic myocardial protection. Ann. Thorac. Surg., 28: 317-318, 1979.

27 CLARK, R. E. - Pharmacologic myocardial protection: a three-phase approach. J. Molec. Cell. Cardiol., 22: (Supl. 5): 5, 1990.

28 CLARK, R. E.; CHRISTHEB, I. Y.; HENRY, P. D.; FISCHER, R. E.; NORA, J. D.; WILLIAMSON, J. R.; SOBEL, B. E. - Nifedipine: a myocardial protective agent. Am. J. Cardiol., 44: 825-831, 1979.

29 COOLEY, D. A.; BEALL Jr., A. C.; GRONDIN, P. - Openheart operations with disposable oxygenators, 5 percent dextrose porcine and normothermia. Surgery, 52: 713-719, 1962.

30 COOLEY, D. A.; REUL, J. J.; WUKASCH, C. - ischemic contracture of the heart: "stone heart". Am. J. Cardiol., 29: 575-577, 1972.

31 DAS, D. K. - Free radicals as mediators of myocardial repertusion injury. J. Molec. Cell. Cardiol., 22: (Supl. 5): 40, 1990.

32 DAVIS, E. J. \& BREMMER, J. - Studies with isolated surviving rat hearts: interdependence of free amino acids and citric-acid-cycle intermediates. Eur. J. Biochem., 38: 86-97, 1973.

33 DIEHL, J. T.; ELCHHORN, E. J.; KONSTAM, M. A.; PAYNE, D. D.; DRESDALE, A. R.; BOJAR, R. M.; RASTEGAR, H.; STETZ, J. J.; SALEM, D. N.; CONNOLLY, R. J.; CLEVELAND, R. J. - Efficacy of retrograde coronary sinus cardioplegia in patients undergoing myocardial revascularization: a prospective randomized trial. Ann. Thorac. Surg., 45: 595-602, 1988.

34 EFFLER, D. B.; GROVES, L. K.; SONE Jr, F. M.; KOLFF, W. J. - Elective cardiac arrest in open-heart surgery. Cleveland Clin. Q., 23: 105-114, 1956.

35 ENGELMAN, R. M.; ROUSOU, J. A.; IYENGAR, J.; DAS, D. K. - Captopril, an ace inhibitor, for reperfusion after acute myocardial infarction. J. Molec. Cell. Cardiol., 22: (Supl 5): 9, 1990. 
BRAILE, D. M.; ARDITO, R. V.; ZAIANTCHICK, M.; SANTOS, J. L. V.; SOARES, M. J. F. - Cardioplegia sangüinea contínua normotérmica. Rev. Bras. Cir. Cardiovasc., 4(2): 109-138, 1989.

36 EZRIN, A.; HORAN, P.; FORT, D.; CANNIFF, P.; HAMEL, D.; LEE, K.; BUSHOVER, C.; GORCZYCA, N.; ETZ. LER, J.; SILVER, P. - Trolox plus vitamin C protects against cardiac perfusion and renal cellular xanthine oxidase-mediated damage. J. Molec. Cell. Cardiol., 22: (Supl 5): 9, 1990.

37 FABIANI, J. N.; DELOCHE, A.; SWANSON, J.; CARPENTIER, A. - Retrograde cardioplegia through the right atrium. Ann. Thorac. Surg., 41: 101-102, 1986.

38 FEINBERG, H.; ROSENBAUM, D. S.; LEVITSKY, S.; SILVERMAN, N. A.; KOHLER, J.; LEBRETON, G. - Platelet deposition after surgically induced myocardial ischemia. An etiologic factor for reperfusion injury. J. Thorac. Cardiovasc. Surg., 84: 815-822, 1982.

39 FEY, K.; FOLLETTE, D.; LIVESAY, J.; NELSON, R.; BUGYI, H.; DELAND, E.; BUCKBERG, G. D. - Effects of membrane stabilization on the safety of hypothermic arrest after aortic cross-clamping. Circulation, 56: (Parte 2): 143-147, 1977.

40 FLAMENG, W. - Calcium autogonists. J. Molec. Cell. Cardiol., 22: (Supl. 5): 43, 1990.

41 FOGLIA, R. P.; STEED, D. L.; FOLLETTE, D. M.; DELAND, E.; BUCKBERG, G. D. - latrogenic myocardial edema with potassium cardioplegia. J. Thorac. Cardiovasc. Surg., 78: 217-222, 1979.

42 FOLLETE, D.; FEY, K.; LIVESAY, J. - The beneficial effects of citrate reperfusion of ischemic heart on cardiopulmonary bypass. Surg. Forum, 27: 244-248, 1976.

43 FOLLETTE, D. M.; FEY, K.; BUCKBERG, G. D.; HELLY, J. J.; STEED, D. L,; FOGLIA, R. P.; MALONEY Jr., J. V. - Reducing postischemic damage by temporary modification of reperfusate calcium, potassium, $\mathrm{pH}$, and osmolarity. J. Thorac. Cardiovasc. Surg., 82: 221-238, 1981.

44 FOLLETTE, D. M.; MULDEI, D. G.; MALONEY, J. V.; BUCKBERG, G. D. - Advantages of blood cardioplegia over continuous coronary perfusion or intermittent ischemia: experimental and clinical study. $J$. Thorac. Cardiovasc. Surg., 76: 604-619, 1978.

FRIDOVICH, I. - The biology of oxigen radicals. Science, 201: 875-880, 1978.

46 FUJIWARA, T.; KURTTS, T.; ANDERSON, W.; HEINLE, J.; MAYER Jr., J.E. - Myocardial protection in cyanotic neonatal lambs. J. Thorac. Cardiovasc. Surg., 96: 700-710, 1988

47 GAY, W. A. \& EBERT, P. A. - Funcional, metabolic, and morphologic effects of potassium - induced cardioplegia. Surgery, 74: 284-290, 1973.

48 GHARAGOZLOO, F.: MELENDEZ, F. J.; HEIN, R. A.; AUSTIN, R. E.; SHEMIN, R. J.; DISESA, V. J.; COHN, L. H. - The effect of oxygen free radical scavengers on the recovery of regional myocardial function after acute coronary occlusion and surgical reperfusion. Surgery, 95: 631-636, 1988
49 GREENFIELD, D. T.; GREENFIELD, L. J.; HESS, M. L - Enhancement of crystalloid cardioplegic protection against global normothermic ischemia by superoxide dismutase plus catalase but not diltiazem in the isolated working rat heart. J. Thorac. Cardiovasc. Surg., 95: $799-813,1988$.

50 GRIEPP, V. B.; STINSON, E. B.; SHUMWAY, N. E. Profound local hypotermia for myocardial protection during open-heart surgery. J. Thorac. Cardiovasc. Surg., 66: 791-841, 1973.

51 GUNDRY, S. R. \& KIRSH, M. M. - A comparison of retrograde cardioplegia versus antegrade cardioplegia in the presence of coronary artery obstruction. Ann. Thorac. Surg., 38: 124-127, 1984.

52 HAMASAKI T., KURODA, H.; MORI, T. - Temperature dependency of calcium induced reperfusion injury in the isolated rat heart. Ann. Thorac. Surg., 45: 306-310, 1988.

53 HEARSE, D. J.; STEWART, D. A.; BRAIMBRIDGE, M V. - Myocardial protection during ischemic cardiac arrest: possible deleterious effects of glicose and mannitol in coronary infusates. J. Thorac. Cardiovasc Surg., 76: 16-23, 1978.

54 HELMSWORTH, J. A.; KAPLAN, S.; CLARKE Jr., L. C.; MCADAMS, A. J.; EDWARDS, F. K. - Myocardial injury associated with asystole induced with potassium citrate. Ann. Surg., 149: 200-208, 1959.

55 HENDREN, W. G.; GEFFIN, F. A.; LOVE, T. R.; TITUS, J. S.; REDONNETT, B. E. - Oxygenation of cardioplegic solutions. J. Thorac. Cardiovasc. Surg., 94: 614-625, 1987.

56 HENDREY, P.; LABOW, R.; AYRES, D.; WATSON, M.; KEON, W. - Temperature and solution composition affect outcome of donor heart preservation. J. Molec. Cell. Cardiol., 22 (Supl 5): 24, 1990.

57 HENRY, P. D.; SHUCHLEIB, R.; BORDA, L. J.; ROBERTS, R.; WILLIAMSON, J. R.; SOBEL, B. E. Effects of nifedipine on myocardial perfusion and ischemic injury in dogs. Circ. Res., 43: 372-380, 1978.

58 HERDY, C. D. C. - Solução cardioplégica com propranolol. Influéncia no consumo de oxigénio pelo miocárdio: estudo experimental. São Paulo, 1984. [Tese. Doutorado. Faculdade de Medicina da Universidade de São Paulo].

59 HEWITT, R. L.; LOLLEY, D. M.; ADROUNY, G. A.; DRA PANAS. T. - Protective effect of glycogen and glycose on the anoxic arrested heart. Surgery, 75:1-11, 1974

60 IMAI, S. \& KITAGAMAU, T. - A comparison of the differential effects of nitroglycerin, nifedipine and papave rine on contractures induced in vascular and intestinal smooth muscle by potassium and lanthanum. Jpn. J. Pharmacol., 31: 193-200, 1981.

61. IYENGAR, J.; KIMURA, Y.; ENGELMAN, R. M.; JONES, R. M.; ROUSOU, J. A.; DAS, D. K. - Cardioprotective 
BRAILE, D. M.; ARDITO, R. V.; ZAIANTCHICK, M.; SANTOS, J. L. V.; SOARES, M. J. F. - Cardioplegia sangüinea contínua normotérmica. Rev. Bras. Cir. Cardiovasc., 4(2): 109-138, 1989.

role of ceruloplasmin, a major copper containning human serum protein. J. Molec. Cell. Cardiol., 22: (Supl. 5): 5,1990 .

62 JAMIESON, W. R. E.; QAYUMI, A. K.; ROSADO, L. J.; TOMLINSON, C. W. - The efficacy of the acute administration of allopurinol and superoxide dismutase in control of ischemia-reperfusion injury in canine model of global ischemia. J. Molec. Cell. Cardiol., 22: (Supl. 5): 9,1990

63 JAZBIK, A. P. - Nova técnica de perfusão retrógrada do miocárdio: estudo clínico e experimental. Rio de Janeiro, 1970. [Tese. Livre-Docência. Faculdade de Medicina da Universidade Federal do Rio de Janeiro].

64 KALONJI, T. T. \& WYSS, M. - Papaverine hydrochloride as an adjunct to cardioplegia? Why not? J. Molec. Cell. Cardiol., 22: (Supl. 5): 34, 1990.

65 KHURI, S. F.; WARNER, K. G.; JOSA, M.; BUTLER, M.; HAYES, A.; HANSON, R.; SLOUFFI, S.; BARSANIAN, E. M. - The superiority of continuous cold blood cardioplegia in the metabolic protection of the hypertrophied human heart. J. Thorac. Cardiovasc. Surg., 95: $442-454,1988$

66 KIMURA, Y.; IYENGAR, J.; ENGELMAN, R. M.; ROUSOU, J. A.; FLACK, J,; DAS, D. K. - Diltiazem and trifluoperazine alone or in combination for myocardial preservation during cardiac surgery. J. Molec. Cell. Cardiol., 22: (Supl 5): 2, 1990.

67 KIRKLIN, J. W.; CONTI, V. R.; BLACKSTONE, E. H. Prevention of myocardial damage during cardiac operation. $\quad$ N. Eng. J. Med., 301: 135-141, 1979.

$68 \mathrm{KIRSCH}$, U.; RODEWALD, G.; KALMAR, P. - Induced ischemic arrest: clinical experience with cardioplegia in open-heart surgery. J. Thorac. Cardiovasc. Surg., 63: 121-130, 1974.

69 KRESH, J. Y.; NASTALA, C.;BIANCHI, P. C.; GOLDMAN, S. M.; BROCKMAN, S. R. - The relative buffering power of cardioplegic solutions. J. Thorac. Cardiovasc. Surg., 93: 309-311, 1987.

70 KUKOVETZ, W. R. \& POCH, G. - Inhibition of cyclic $3^{\prime}, 5^{\prime}$ nucleotide phosphodiesterase as a possible mode of action of papaverine and similarly acting drugs. Arch. Pharm., 267: 189-194, 1970.

71 KURKJI, H.; DELAND, E.; BUCKBERG, G. D. Prevention of ischemic myocardial contracture (stone heart). Surg. Forum, 44: 146-150, 1973.

72 LABOW, R. S.; MEEK, E.; HENDRY, P. J.; KEON, W. J. - Temperature affects human sarcoplasmic reticulum calcium ATPase. J. Molec. Cell. Cardiol., 22: (Supl 5): 12, 1990.

73 LANGER, G. A. - Control of calcium movement in the myocardial. Eur. Heart J., 4 (Parte 2): 5-11, 1983.

74 LANGER, G. A. - The structure and function of the myocardial cell surface. Am. J. Physiol., 235 (Parte 3): $164,1978$.
75 LAZAR, H. L.; BUCKBERG, G. D.; FOGLIA, R. P.; MANGANARO, A. G.; MALONEY, Jr., J. V. - Detrimental effects of premature use of inotropic drugs to discontinue cardiopulmonary bypass. J. Thorac. Cardiovasc. Surg., 82: 18-25, 1981.

76 LAZAR, H. L.; BUCKBERG, G. D.; MANGANARO, A J.; FOGLIA, R. P.; BECKER, H.; MULDER, D. G.; MALONEY Jr., J. V. - Reversal of ischemic damage with secondary blood cardioplegia. J. Thorac. Cardiovasc. Surg., 78: 688-697, 1979.

77 LAZAR, H. L.; BUCKBERG, G. D.; MANGANARO, A. M.; BECKER, H. - Myocardial energy replenishment and reversal of ischemic damage by substrate enhancement of secondary blood cardioplegia with amino acids during reperfusion. J. Thorac. Cardiovasc. Surg., 80: 350-359, 1980.

78 LAZAR, H. L.; RAJAII, A.; ROBERTS, A. J. - Reversal of repertusion injury after ischemic arrest with pressurecontrolled intermittent coronary sinus occlusion. J. Thorac. Cardiovasc. Surg., 95: 637-742, 1988.

79 LAZAR, H. L.; WILCOX, K.; HANKINS, T.; PLEHN, J.; ROBERTS, A. J. - Effects of left ventricular venting and distention during heterogeneous distribuiton of cardioplegic solution. J. Thorac. Cardiovasc. Surg., 95: 501-507, 1988.

80 LEDINGHAM, S. J. M.; BRAIMBRIDGE, M. V.; HEARSE, D. J. - Improved myocardial protection by oxygenation of the St. Thomas' Hospital cardioplegic solutions: study in the rat. J. Thorac. Cardiovasc. Surg., 95: 103-111, 1988.

81 LEVITSKY, S. - Another look at reperfusion asystole. Ann. Thorac. Surg., 45: 471-472, 1988.

82 LEVITSKY, S.; WRIGHT, R. N.; RAO, K. S.; HOLLAND, C.; ROPER, K.; ENGELMAN, R.; FEINBERG, H. Does intermittent coronary perfusion offer greater myocardial protection than continuous aortic cross-clamping? Surgery, 82: 51-59, 1977.

83 LICHTENSTEIN, S. V.; ASHE, K. A.; CUSIMARO, R. J.; PANOS, A.; SLUTSKY, A. S. - Warm heart surgery. J. Thorac. Cardiovas. Surg., (No prelo).

84 LICHTENSTEIN, S. V.; EL-DALATI, H.; PANOS, A.; SLUTSKY, A. S. - Long cross-clamp with warm heart surgery. Lancet, 1: 1443, 1989. (Carta ao editor).

85 LICHTENSTEIN, S. V.; SALERNO, T. A.; SLUTSKY, A S. - Warm continuous cardioplegia is preferable to intermittent hypothermic cardioplegia for myocardial protection during cardiopulmonary bypass: pro and con. J. Cardiothorac. Anesth., 4: 279-283, 1990.

86 LIU, X.; ENGELMAN, R. M.; ROUSOU, J. A.; DAS, D K. - Attenuation of myocardial reperfusion injury by angiotensin converting enzyme (ACE) inhibitors: a comparison of captopril (C), zofenopril (Z) and fosinopril (F). J. Molec. Cell. Cardiol., 22: (Supl 5): 4, 1990. 
BRAILE, D. M.; ARDITO, R. V.; ZAIANTCHICK, M.; SANTOS, J. L. V.; SOARES, M. J. F. - Cardioplegia sangüínea contínua normotérmica. Rev. Bras. Cir. Cardiovasc., 4(2): 109-138, 1989.

87 LOOP, F. D. - Myocardial protection in reoperative coronary artery surgery. J. Molec. Cell. Cardiol., 22: (Supl. 5): $44,1990$.

88 LYNCH, M. J.; BOVE, E. L.; ZWENG, T. N.; FOX, M. H.; BOLLING, S. F.; GALLAGHER, K. P. - Protection of the neonatal heart following normothermic ischemia: a comparison of oxygenated saline and oxygenated versus nonoxygenated cardioplegia. Ann. Thorac. Surg., 45: 650-655, 1988.

89 MAGOVERN, J. A.; PAE, W. E.; WALDhAUSEN, J. A. - Protection of the immature myocardium. J. Thorac. Cardiovasc. Surg., 96: 408-413, 1988

90 MAGOVERN Jr., G. J.; BOLLING, S. F.; CASALE, A. S.; BULKLEY, B. H.; GARDNER, T. J. - The mechanism of mannitol in reducing ischemic injury: hyperosmolarity or hydroxyl scavenger? Circulation, 70 (Supl. 1): 91-95, 1984.

91 MAXWELL, L. \& GAVIN, J. B. - The role of oxygen free radicals in the pathogenesis of post-ischaemic vascular incompetence in the myocardium. J. Molec. Cell. Cardiol., 22: (Supl. 5): 7, 1990.

92 McCORD, J. M. \& FRIDOVICH, I. - Superoxide dismutase: an enzimic function for erytroprein (hemocuprein). J. Biol. Chem., 244: 6049-6055, 1969.

93 McGOON, D. C. - The engoing quest for ideal myocardial protection: a catalog of the recent english literature. J. Thorac. Cardiovasc. Surg., 89: 639-53, 1985. (Editorial).

94 McGOON, D. C. - The quest for ideal myocardial protection. J. Thorac. Cardiovasc. Surg., 79: 150, 1980. (Editorial).

95 MELENDEZ, F. J.; GHARANGOZLOO, F.; SUN, S. C.; BENFELL, K.; AUSTIN, R. E.; SHEMIN, R. J.; COHN, L. H. - Effects of diltiazem cardioplegia on global function, segmental contractility, and the area of necrosis after acute coronary artery occlusion and surgical repertusion. J. Thorac. Cardiovasc. Surg., 95:613-617, 1988.

96 MELROSE, D. J.; DREYER, B.; BENTALL, H. H.; BAKER, J. B. E. - Elective cardiac arrest: a preliminary communication. Lancet, 2: 21-22, 1955

97 MENASCHE, P.; KURAL, S.; FAUCHET, M.: LAVERGINE, A.; COMMIN, P.; BERCOT, M.; TOUCHOT, B.; GEORGIOPOULOS, G.; PIWNICA, A. - Retrograde coronary sinus perfusion: a safe alternative for ensuring cardioplegic delivery in aortic valve surgery. Ann. Thorac. Surg., 34: 647-657, 1982.

98 MENASCHE, P.; PASQUIER, C.;BELLUCCI, S.; LORENTE, P.: JAILLON, P.: PIWNICA, A. - Deferoxamine reduces neutrophil-mediated free radical production during cardiopulmonary bypass in man. $J$. Thorac Cardiovasc. Surg., 96: 582-589, 1988.

99 MENASCHE, P. \& PIWNICA, A. - Retrograde cardioplegia through the coronary sinus. Ann. Thorac. Surg., 44: 214-216, 1987
100 MENKIS, A. H.; NOVICK, R. J.; POWELL, A. M.; PFLUGFELDER, P. W.; KOSTUK, W. J.; MCKENZIE, F. N. - Extended donor ischemic time using crystalloid cardioplegia and high storage temperature. J. Molec. Cell. Cardiol., 22: (Supl. 5): 27, 1990.

101 MULLEN, J. C.; KHAN, N.; WEISEL, R. D.; CHRISTAKIS, G. T.; TEOH, K. H.; MICKLE, D. A. G.; IVANOV, J. - Atrial activity during cardioplegia and postoperative arrhythmias. J. Thorac. Cardiovasc. Surg., 94: 558-565, 1987.

102 MURAD, F.; ARNOLD, W. P.; MITTAL, C. K. - Properties of and regulation of guanylate cyclase and some proposed functions for cyclic GMP. In: GREENGARD, P. \& ROBISON G. A. (eds.) - Advances in cyclic nucleotide research. New York, Raven, 1979, vol. 2, p. 175-204.

103 NAYLER, W. G. - Protection of the myocardium against postischemic reperfusion damage: the combinate effect of hypothermia and infedipine. J. Thorac. Cardiovasc. Surg., 84: 897-905, 1982.

104 NAYLER, W. G. - Reperfusion injury: ions and catecholamines (an overview). J. Molec. Cell. Cardiol., 22: (Supl. 5): 40, 1990.

105 NAYLER, W. G.; FERRARI, R.; WILLIAMS, A. - Protective effect of pretreatment with verapamil, nifedipine and propanolol on mitochondrial function in the ischemic and reperfused myocardium. Am. J. Cardiol., 46: 242-248, 1980.

106 NOVICK, R. J.; STEFANISZYN, H. J.; MICHEL, R. P.; BURDON, F. D.: SALERNO, T. A. - Protection of the hypertrophied pig myocardium. J. Thorac. Cardiovasc. Surg., 89: 547-566, 1985.

107 OHASHI, T.; YAMAMOTO, F.; MURASHITA, T.; ICHIKAWA, H.; KOMAI, H.; SHIBATA, T.; KOIDE, A.; YAGHIHARA, T.; FUJITA, T. - Effects of spin trap agents on myocardial ischemia and reperfusion injury in the isolated rat heart. J. Molec. Cell. Cardiol., 22: (Supl. 5): 8,1990 .

108 OTANI, H.; ENGELMAN, R. M.; DATTA, S.; JONES, R. M.; CORDIS, G. A.; ROUSOU, J. A.; BREYER, R. H.; DAS, D. K. - Enhanced myocardial preservation by nicotinic acid, and antilipolytic compound. J. Thorac. Cardiovasc. Surg., 96: 81-87, 1988.

109 PANOS, A.; CHRISTAKIS, G. T.; LICHTENSTEIN, S. V.; WITTNICH, C.; EL-DALATI, H.; SALERNO, T. A. Operation for acute post-infarction mitral insufficiency using continuous oxygenated blood cardioplegia. Ann. Thorac. Surg., 48: 816-819, 1989.

110 PANOS, A.; SALERNO, T. A.; LICHTENSTEIN, S. V. Continuous warm blood cardioplegia in surgery for acute postinfarction mitral insufficiency. J. Molec. Cell. Cardiol., 22: (Supl. 5): 31, 1990.

111 PRASAD, M. R.; ROUSOU, J. A.; ENGELMAN, R. M.; LIU, X.; NATH, D.; DAS, D. K. - Reduced free radical generation during reperfusion of hypothermically arrested heart. J. Molec. Cell. Cardiol., 22: (Supl. 5): 7. 1990. 
BRAILE, D. M.; ARDITO, R. V.; ZAIANTCHICK, M.; SANTOS, J. L. V.; SOARES, M. J. F. - Cardioplegia sangüinea contínua normotérmica. Rev. Bras. Cir. Cardiovasc., 4(2): 109-138, 1989.

112 PEYTON, R. B.; TRIGT, P.; PELLOM, G. L.; JONES, R. N.; SINK, J. D.; WECHSLER, A. S. - Improved tolerance to ischemia in hypertrophied myocardium by preischemic enhancement of adenosine triphosphate. J. Thorac. Cardiovasc. Surg., 84: 11-15, 1982.

113 POOLE-WILSON, P. A. - Ischaemia and reperfusionions, channels and receptors. J. Molec. Cell. Cardiol., 22: (Supl. 5): 39, 1990.

114 PRATT, F. H. - The nutrition of the heart through the vessels of Thebesius and the coronary veins. $A m$. J. Physiol., 1: 86-103, 1898.

115 PRIDJIAN, A. K.; LEVITSKY, S.; KRUKENKAMP, I.; SILVERMAN, N. A.; FEINBERG, H. - Development changes in reperfusion injury: a comparison of intracellular cation accumulation in newborn neonatal, and adult heart. J. Thorac Cardiovasc Surg., 93: 428-433, 1987.

116 QIU, Y,; GALINAMES, M.; EZRIN, A.; HEARSE, D. J. - Peg-sod improves protection against normothermic global ischaemia in the blood perfused rabbit heart. J. Molec. Cell. Cardiol., 22: (Supl. 5): 10, 1990.

117 RICH, T. L. \& BRADY, A. J. - Potassium contracture and utilization of high-energy phosphates in rabbit heart. Am. J. Physiol, 226: 105-109, 1974.

118 ROBINSON, L. A.; BRAIMBRIDGE, M. V.; HEARSE, D. J. - Enhanced myocardial protection with high-energy phosphates in St. Thomas' Hospital cardioplegic solution: synergism of adenosine triphosphate and creatine phosphate. J. Thorac. Cardiovasc. Surg., 93: 415-427, 1987.

119 ROE, B. B.; HUTCHINSON, J. C.; FISHMAN, N. H.; ULLYOT, D. J.; SMITH, D. L. - Myocardial protection with cold ischemic, potassium-inducd cardioplegia. J. Thorac. Cardiovasc Surg., 73: 366-374, 1977.

120 ROSENKRANZ, E. R.; BUCKBERG, D. G.; LAKS, H.; MULDER, D. G. - Warm induction of cardioplegia with glutamate-enriched blood in coronary patients with cardiogenic shock who are dependent on inotropic drugs and intra-aortic balloon support. J. Thorac. Cardiovasc. Surg., 86: 507-518, 1983.

121 ROSENKRANZ, E.; OKAMOTO, F.; BUCKBERG, G. D.; ROBERTSON, J. M.; VINTEN-JOHANSEN, J. - Safety of prolonged aortic clamping with blood cardioplegia. J. Thorac. Cardiovasc. Surg., 91: 428-435, 1986.

122 ROSENKRANZ, E. R.; OKAMOTO, F.; BUCKBERG, G. D.; VINTEN-JOHANSEN, J.; EDWARDS, H.; BUGYI, H. - Advantages of glutamate-enriched cold blood cardioplegia in energy-depleted hearts. Circulation, 66: (Parte 2): 151, 1982.

123 ROSENKRANZ, E. R.; VINTEN-JOHANSEN, J.; BUCKBERG, G. D.; OKAMOTO, F.; EDWARDS, H.; BUGIY, H. I. - Benefits of normothermic induction of blood cardioplegia in energy-depleted hearts with maintenance of arrest by multidose cold blood cardioplegic infu- sion. J. Thorac. Cardiovasc. Surg., 84: 667-677, 1982.

124 ROUSOU, J. A.; ENGELMAN, R. M.; BREYER, R. H.; OTANI, H.; LEMESHOW, S.; DAS, D. K. - The effect of temperature and hematocrit level of oxygenated cardioplegic solutions on myocardial preservation. $J$. Thorac. Cardiovasc. Surg., 95: 625-630, 1988.

125 ROVETTO, M. J.; WHITMER, S. B.; NEELY, J. R. Comparison of the effects of anoxia and whole heart ischemia on carbohydrate utilization in isolated working rat hearts. Circ. Res., 32: 699-704, 1973.

126 SALERNO, T. A.; HOUCK, J. P.; BARROZO, C. A. M.; PANOS, A.; CHRISTAKIS, G. T.; ABEL, J. G.; LICHTENSTEIN, S. V. - First clinical report on retrograde continuous warm blood cardioplegia. (No prelo).

127 SHEN, A. C. \& HENNINGS, R. B. - Kineties of calcium acumulation in acute myocardial ischemic injury. $\mathrm{Am}$. J. Pathol., 67: 441-452, 1972.

128 STEWART, J. R.; BLACKWELL, W. H.; CRUTE, S. L.; LOUGHLIN, V.; GREENFIELD, L. J.; HESS, M. L. Inhibition of surgically induced ischemia/reperfusion injury by oxygen free radical scavengers. J. Thorac. Cardiovasc. Surg., 86: 262-272, 1983.

129 SILVERMAN, N. A.; KOHLER, J.; LEVITSKY, S.; PAVEL, D. G.; FANG, R. B.; FEINBERG, H. - Chronic hypoxemia depresses global ventricular function and predisposes to the depletion of high-energy phosphates during cardioplegic arrest: implications for surgical repair of cyanotic congenital heart defects. Ann. Thorac. Surg., 37: 304-308, 1984.

130 SINK, J. D.; PELLOM, G. L.; CURRIE, W. D.; HILL, R. C.; OLSEN, C. O.; JONES, R. N.; WECHSLER, A. S. - Response of hypertrophied myocardium to ischemia: correlation with biochemical and physiological parameters. J. Thorac. Cardiovasc. Surg., 81: 865-872, 1981.

131 STEINBERG, J. B.; DOHERTY, N. E.; MUNFAKH, N. A.; GEFFIN, G.; TITUS, J. S.; HOAGLIN, D. C.; DENENBERG, A. G.; DAGGETT, W. M. - The addition of glucose and insulin to an oxygenated cardioplegic solutions (C5). J. Molec. Cell. Cardiol., 22: (Supl. 5): 13, 1990.

132 SOlORZANO, J.; TAITELBAUM, G.; CHIU, R. - Retrograde coronary sinus perfusion for myocardial protection during cardiopulmonary bypass. Ann. Thorac. Surg., 25: 201-208, 1978.

133 SUN, S. C.; RAZA, S. T.; TAM, S. K. C.; LAURENCE, R.; COHN, L. H. - Effects of antegrade cardioplegic infusion with simultaneously controlled coronary sinus occlusion on preservation of regionally ischemic myocardium after acute coronary artery occlusion and reperfusion. J. Thorac. Cardiovasc. Surg., 96:626-633, 1988. 
BRAILE, D. M.; ARDITO, R. V.; ZAIANTCHICK, M.; SANTOS, J. L. V.: SOARES, M. J. F. - Cardioplegia sangüinea contínua normotérmica. Rev. Bras. Cir. Cardiovasc., 4(2): 109-138, 1989.

TABAYASHI, K.; MCKEOWN, P. P.; MIYAMOTO, M. LUEDTKE, A. E.; THOMAS, R.; ALLEN, M. D.; MISBACH, G. A.; IVEY, T. D. - Ischemic miocardial protection: comparison of nonoxygenated crystalloid, and oxigenated fluorocarbon cardioplegic solutions. J. Thorac. Cardiovasc. Surg., 95: 239-246, 1988.

TAYLER, R. L.; NORRIS, S. E.; CHIDONI, J. J. —-Addition of diltiazem enhances cold potassium cardioplegia. Surg. Forum, 37: 238-243, 1986.

TEOH, K. H.;MICKLE, D. A. G.; WEISEL, R. D.; MADO NIK, M. M.; IVANOV, J.; HARDING, R. D.; ROMASCHIN, A. D.; MULLEN, J. C. - Improving myocardial metabolic and functional recovery after cardioplegic arrest. J. Thorac. Cardiovasc Surg., 95: 788-798, 1988.

THORELIUS, J.; THELIN, S.; RONQUIST, G.; HALDÉN E.; HANSSON, H. E. - Creatine phosphate supplementation of cardioplegia: a clinical study. J. Molec. Cell. Cardiol., 22: (Supl. 5): 30, 1990.

TORCHIANA, D. F.; LOVE, T. R.; HENDREN, W. G. GEFFIN, G. A.; TITUS, J. S.; REDONNET, B. E.; O KEEFE, D. D.; DAGGETT, W. M. - Calcium-induced ventricular contraction during cardioplegic arrest. J. Thorac. Cardiovasc. Surg., 94: 606-613, 1987.

TYERS, G. F. O.; HUGHES, H. C.; TODD, G. J.; WILLIAMS, D. R.; ANDRES, E. J.; PROPHET, G. A.; WAL DHAUSEN, J. A. - Protection from ischemic cardiac arrest by coronary perfusion with cold ringer's lactate solution. J. Thorac. Cardiovasc. Surg., 67: 411-418, 1974.

140 TYERS, G. F. O.; TODD, G. J.; NIEBAUER, I. M.; MANLEY, N. J.; WALDHAUSEN, J. A. - The mechanism of myocardial damage following potassium citrate (Melrose) cardioplegia. Surgery, 78: 45-53, 1975.

VALENZA, M.; SERBINOVA, E.; KAGAN, V.; KHWAJA, S.; ALBIERO, R.; PACKER, L. - Protective effects of $\mathrm{L}$-propionylcarnitine during ischemia and reperfusion in the isolated Langendorff perfused rat heart. J. Mo. lec. Cell. Cardiol., 22: (Supl 5): 6, 1990.

VANDER WOUDE, J. C.; CHRISTLIEB, I. Y.; SICARD, G. A. et al - imidazole-buffered cardioplegic solution: improved myocardial preservation during global ischemia. J. Thorac. Cardiovasc. Surg., 90: 225-232, 1985.

WALDHAUSEN, J. A.; BRAUNWALD, N. S.; BLOODWELL, R. D.; CORNELL, W. P.; MORROW, A. G. Left ventricular function following elective cardiac arrest. J. Thorac. Cardiovasc. Surg., 39: 799-807. 1960
145 WARNER, K. G.; JOSA, M.; BUTLER, M. D.; GHERARDI, P. C.; ASSOUSA, S. N.; SAAD, A. J.; SIOUFFI, S.; BARSAMIAN, E. M.; KHURI, S. F. - Regional changes in myocardial acid production during ischemic arrest: a comparison of sanguineous and asanguineous cardioplegia. Ann. Thorac. Surg., 45: 75-81, 1988.

146 WILLENTHAL, K.; MIETZWIAK, D. S.; MITCHELL, J. I. L. - Acute effects of increased serum osmolarity on left ventricular performance. Am. J. Physiol., 216: 898-904, 1969.

147 WILLERSON, J. T.; POWELL, J.; GUINEY, T. E.; STARK, J. J.; SANDERS, C. A.; LEAF, A. - Improvement in myocardial function and coronary blood flow in ischemic myocardium after mannitol. J. Clin. Invest., 51: 2989-2998, 1972.

148 WIT, L.; COETZEE, A.; KOTZE, J.; LOCHNER, A. Oxygen requirements of the isolated rat heart during hypothermic cardioplegia: effects of oxygenation on metabolic and functional recovery after five hours of arrest. J. Thorac. Cardiovasc. Surg., 95: 310-320, 1988.

149 YAMAMOTO, F.; MANNING, A. S.; BRAIMBRIDGE, M. V.; HEARSE, D. J. - Cardioplegia and slow calcium channel blockers: studies with verapamil. J. Thorac. Cardiovasc Surg., 86: 252-262, 1983.

AGRADECIMENTO: Este trabalho foi desenvolvido com a colaboração da Divisão de Pesquisas e Publicações (DPP) da IMC-Biomédica e do Centro de Processamento de Dados do IMC (CPD-IMC). Nossos agradecimentos a esses dois setores.

\section{Discussão}

\section{DR. PAULO R. BROFMAN Curitiba, $P R$}

A lesão causada ao miocárdio no trans-operatório é a causa mais comum de morbidade e mortalidade após a correção cirúrgica de cardiopatias, sejam elas congênitas ou adquiridas. Mais de $90 \%$ dos pacientes que não sobrevivem ao período per-operatório, de acordo com vários autores, apresentam, na avaliação post mortem, alteraçōes macroscópica, microscópica ou histoquímica de necrose do miocárdio em diferentes graus, comprometendo, mais comumente, o subendocárdio, seja de ventrículo esquerdo ou direito. Não se tem dúvida de que a proteção miocárdica representa a mais importante conquista na diminuição de mortalidade per-operatória, bem como na melhoria dos resultados tardios. O trabalho apresentado pelos autores chama a atenção, ao nosso ver, em dois aspectos que, se não são novidade, mudaram a história da cardioplegia. O primeiro deles é a cardioplegia sangüinea. A necessidade de oxigenar uma solução cardioplégica tem sido defendida por vários autores, como Kirklin e Buckberg, que demonstraram 
BRAILE, D. M.; ARDITO, R. V.; ZAIANTCHICK, M.; SANTOS, J. L. V.; SOARES, M. J. F. - Cardioplegia sangüínea contínua normotérmica. Rev. Bras. Cir. Cardiovasc., 4(2): 109-138, 1989.

a superioridade destas soluçōes oxigenadas em relação às não oxigenadas. $O$ veículo para prover oxigênio pode ser o sangue, o fluocarbono, o estroma de hemoglobina livre, ou a dissoluçāo direta no cristalóide. O sangue é o escolhido por ser o mais fisiológico e facilmente obtido durante a circulação extracorpórea, apesar de alguns inconvenientes, como a temperatura alterar desfavoravelmente a curva de dissociação da oxi-hemoglobina, resultante em menor carga de oxigênio a nível celular, ou, ainda, a complexidade de sistema para misturar as soluçōes de cardioplegia com sangue. A cardioplegia normotérmica proposta pelo grupo do Dr. Tomás Salerno e pelo autor deste trabalho seria vantajosa na manutenção da oxigenação e do metabolismo aeróbio. Os "sistemas" de cardioplegia sangüínea com diluidores 1:2 ou 1:4 estão bastante estandardizados e difundidos em um grande número de Serviços, na América do Norte e aqui no País, pelo autor deste trabalho. O segundo aspecto e á reperfusão assistólica para evitar a lesão da reperfusāo. Essa lesāo é determinada pela impossibilidade de manter o cálcio seqüestrado. Muitos autores demonstram que o coraçāo, durante a isquemia, fica sensibilizado para sofrer a lesão tecidual que, de fato, ocorre durante a reperfusão. Buckberg chega a afirmar que o cirurgiāo cardíaco é o único capaz de neutralizar o potencial dessa lesão, porque a condição de reperfusão e a composição do reperfusato estão sob seu controle. A reperfusāo com solução de cardioplegia sangüinea quente por alguns minutos tem minimizado essa lesão. A concentração baixa de potássio (8-10 mEG/1) e o efeito aditivo do uso de aspartato de sódio, quando empregado em conjunto com o glutamato na solução, são fundamentais na reversão do dano isquêmico e desenvolvimento do trabalho cardíaco mais efetivo após a isquemia. Muito obrigado.

\section{DR. DOMINGOS JUNQUEIRA DE MORAES Rio de Janeiro, RJ}

Em primeira lugar, desejamos agradecer à Comissão Organizadora a gentiliza de nos convidar para sermos um dos Comentadores Oficiais deste trabalho. Além das informaçōes e conceitos apresentados, o trabalho tem, especialmente, valor pela autoridade do autor que, entre nós, tem sido, provavelmente, o mais entusiasta estudioso deste problema. Eu devo dizer que, por coincidência, na primeira intervenção que realizei com circulação extracorpórea, em 1958, utilizei a técnica de Melrose, para corrigir comunicação interventricular em paciente com CIV e hipertensão pulmonar, de 20 anos de idade. O clampeamento aórtico foi de 30 minutos e o resultado imediato, muito satisfatório. O paciente apresentou deiscência de esterno com infecção de mediastino, que o levou ao óbito na terceira semana pós-operatória. Entretanto, nestes 30 anos decorridos, não tenho sido dos mais entusiastas do uso rotineiro da cardioplegia, em cirurgia cardíaca, a não ser na cirurgia da valva aórtica. Tenho usado mais a técnica de parada anóxica intermitente, fibrilação ventricular e hipotermia sistêmica, com a qual tenho tido bons resultados. Há muitos cirurgiōes experimentados, como os Drs. D. Johnson, dos EUA, lacoub, da Inglaterra, Sebenıng, de Munique, Adib Jatene e Régis Jucá, do Brasil, para citarmos apenas alguns que continuam usando a parada anóxica com clampeamento intermintente. Temos de admitir que há, atualmente, uma imensa quantidade de informaçōes sobre o metabolismo cardíaco submetido a isquemia e várias maneiras de se evitarem danos maiores ao miocárdio, desde que se obedeçam os critérios conhecidos, como muito bem demonstrado está no presente trabalho. Entretanto, não se pode negar que o clampeamento intermitente da aorta é o método mais simples e aquele que está envolvido em menor número e variáveis tais como: composição de soluções cardioplégicas, $\mathrm{pH}$, osmolaridade, temperatura, volume necessário, etc., etc. Em setembro de 1988, o Dr. Ciro Herdy, da nossa equipe, apresentou, no último Congresso de Cardiologia, em Belém, nossos resultados preliminares com a técnica ora descrita pelo Dr. Domingo Braile. Haviamos tomado conhecimento dessa técnica no Serviço do Dr. Tomás Salerno, em Toronto, há dois anos. Dessa data para cá, estamos usando, rotineiramente, essa técnica, mas sem a adição de "removedores", ou substratos bioquímicos. A nossa impressão é muito favorável, não só pela facilidade e simplicidade no ato cirúrgico, mas também pelos resultados obtidos. Gostaria de fazer um comentário sobre os métodos usados para corrigir as lesões isquêmicas, ou de reperfusão que podem ocorrer, apesar de todos os cuidados durante a intervenção. O Dr. Buckberg publicou, no "Cardiac Surgery", um trabalho sob o título "Progress in Myocardial Protection During Cardiac Operations". Observa-se que é indiscutivel, do ponto de vista fisiológico, qual a melhor maneira de se recuperar o coração, que, ao final da perfusão, constatamos que apresenta lesão isquêmica, ou de reperfusão. Em nossa experiência, temos mantido o paciente durante período mais ou menos prolongado (4 a 8 horas) em bypass total, com ventrículo esquerdo totalmente descomprimido e oxigenação predominante pelos pulmōes. Uma pequena hipóxia é tolerada, desde que a saturação arterial permaneça em torno de $90 \%$ e a saturação venosa, acima de $70 \%$. Nossa casuística é pequena, mas nos parece encorajadora, pela simplicidade de ser instituida no final da intervençāo, com o mesmo material usado durante a cirurgia. Recentemente, tivemos um paciente em que este método foi usado por seis horas, obtendo-se evolução muito favorável, com alta hospitalar dentro de duas semanas. Novamente, desejo congratular-me com os autores e agradeço o privilégio de ter comentado este importante trabalho.

\section{DR. BRAILE} (Encerrando)

Agradeço os comentários de tão renomados colegas, que vieram valorizar a minha apresentação. Acredito que os processos de proteção miocárdica estão em evoluçāo e o que buscamos, hoje, não é simplesmente 
BRAILE, D. M.; ARDITO, R. V.; ZAIANTCHICK, M.; SANTOS, J. L. V.; SOARES, M. J. F. - Cardioplegia sangüínea contínua normotérmica. Rev. Bras. Cir. Cardiovasc., 4(2): 109-138, 1989.

proteger o coração durante a parada cardíaca, mas também ressuscitá-lo. Desta forma, concordo que existem muitas maneiras, algumas delas simples, de se conseguir proteção miocárdica, como exemplo o clampeamento aórtico intermitente hiportérmico, ou até normotérmico, desde que nāo se exceda o periodo de isquemia de mais ou menos 10 minutos. Porém, se desejarmos restaurar as condiçōes energéticas de um miocárdio com déficits, necessitamos realizar procedimentos que permitam tal recuperação. Acreditamos que a indução cardioplégica sangüínea normotérmica oxigenada com o uso de aminoácidos, assim como a cardioplegia contínua, ou a mais contínua possivel usando-se a mesma composição cardioplégica apenas com diminuição da concentração do potássio, e, ainda, a reperfusão assistólica com a mesma solução por 4 a 5 minutos podem melhorar a performance do miocárdio, a ponto de permitirem operaçōes em pacientes muito graves, sem que apareçam, no pós-operatório, sinais de baixo débito e, muito pelo contrário, tais pacientes têm apresentado um aumento do índice cardiaco e do trabalho cardíaco sem necessidade de qualquer suporte inotrópico ou mecânico. 